NBER WORKING PAPER SERIES

\title{
CHANGES IN MARRIAGE AND DIVORCE AS DRIVERS OF EMPLOYMENT AND RETIREMENT OF OLDER WOMEN
}

\author{
Claudia Olivetti \\ Dana E. Rotz \\ Working Paper 22738 \\ http://www.nber.org/papers/w22738 \\ NATIONAL BUREAU OF ECONOMIC RESEARCH \\ 1050 Massachusetts Avenue \\ Cambridge, MA 02138 \\ October 2016
}

The views expressed in this paper are those of the authors and do not necessarily represent the opinions of their respective institutions, nor of the National Bureau of Economic Research. This paper was prepared for the Women Working Longer Conference hosted by the National Bureau of Economic Research in Cambridge, MA on May 21-22, 2016. We thank Jesse Bruhn, Marco Ghiani, Elias Sanchez-Eppler, and James Ledoux who provided expert research assistance. We also thank Claudia Goldin, Larry Katz, Yue Li, Alessandra Voena and participants in the "Women Working Longer" conference for valuable comments and suggestions. We gratefully acknowledge the financial support of the Alfred P. Sloan Foundation's Working Longer program under grant no. 2013-6-16, "Women Working Longer."

NBER working papers are circulated for discussion and comment purposes. They have not been peer-reviewed or been subject to the review by the NBER Board of Directors that accompanies official NBER publications.

(C) 2016 by Claudia Olivetti and Dana E. Rotz. All rights reserved. Short sections of text, not to exceed two paragraphs, may be quoted without explicit permission provided that full credit, including $\odot$ notice, is given to the source. 
Changes in Marriage and Divorce as Drivers of Employment and Retirement of Older Women

Claudia Olivetti and Dana E. Rotz

NBER Working Paper No. 22738

October 2016

JEL No. J12,J21,J22

\begin{abstract}
$\underline{\text { ABSTRACT }}$
We study associations among women's current marital status, past marital history, and later-life labor force participation. We first document these relationships using data from the 1986 to 2008 waves of the Survey of Income and Program Participation (SIPP). We then exploit variation in laws governing divorce across states and over time to quasi-experimentally identify how the timing of an exogenous increase in divorce risk (that is, the introduction of unilateral divorce) impacts employment and retirement outcomes for older women. The spread of unilateral divorce, we find, was associated with cross-cohort differences in the probability of divorce over the lifecycle. For women with a low risk of divorce, later exposure to unilateral divorce significantly increases the probability of full-time employment later in life, and significantly decreases retirement wealth. This finding suggests that ever-divorced women are working longer remedially; when a woman unexpectedly divorces later in life, she is less likely to have engaged in precautionary human capital investment and might have to work longer to increase her assets prior to retirement. For women with a high risk of divorce, later exposure to increases in divorce risk does not impact full-time employment after age 50 but is positively associated with investment in education post marriage. These women invest more in their own human capital within marriage, which might insure them against increases in exogenous divorce risk at later ages.
\end{abstract}

Claudia Olivetti

Boston College

Department of Economics

Maloney Hall

Chestnut Hill, MA 02467

and NBER

claudia.olivetti@bc.edu

Dana E. Rotz

Mathematica Policy Research

955 Massachusetts Ave.,

Suite 801

Cambridge, MA 02139

drotz@mathematica-mpr.com 


\section{Introduction}

Employment and marital history are both important determinants of labor force participation and financial security at later ages. But these outcomes and their relationships vary significantly by gender, education, and cohort. Understanding how employment and marital history impact later life outcomes is particularly relevant for today's older women who have substantially higher labor force participation rates than past cohorts (cf. Goldin and Katz, this volume, for evidence and discussion of determinants).

Marital status and marital history both shape employment behavior at later ages. Current marital status influences employment in the established way. But marital history is also important, as past marriages and divorces shape previous economic decisions and the processes of human and financial capital accumulation, and thus can have large impacts on a woman's budget set and choices at later ages. In a life-cycle perspective, the age at which a woman experiences a divorce might matter because it could affect the probability of re-marriage and her ability to invest in human and financial capital. Increased divorce risk might also impact the work decisions of a married woman through changes in household bargaining power and economic incentives throughout married life. In the face of higher divorce risk, which increases the probability of being in a low consumption state in the future, married women have had an increased incentive to enhance their own earning potential through labor market experience, education, and/or occupational choice, as a kind of self-insurance (Greene and Quester, 1982; Johnson and Skinner, 1986). Moreover, if divorce is more likely, women can anticipate spending less of their adult life in marriage, thus reducing the returns from specializing in home production (Stevenson, 2007). Increases in divorce risk might also affect married women’s propensity to save and accumulate financial capital (Voena, 2015).

The literature on retirement security has shown the importance of marital history in determining later-life economic outcomes, focusing mostly on women in the 1930 to 1949 birth cohorts (e.g., Couch et al., 2011; Holden and Fontes, 2009; Munnell, 2004; Tamborini, Iams, and Ulker, 2009; Vespa and Painter, 2011; Whitman 2009; Wilmoth and Koso, 2002; Zagorsky, 2005; Zissimopoulus, Karney, and Rauer, 2015). The women in these cohorts had relatively low labor force attachment. Thus, their financial positions at later ages are intimately linked to their husbands' income and savings behaviors. We argue that these cohorts of women were also likely 
to have been greatly disadvantaged by the (probably unexpected) shift from consent to unilateral divorce that was associated with a large temporary increase in divorce rates (Friedberg, 1998; Wolfers, 2006).

Economists have previously used the shift to unilateral divorce to study the effects of divorce laws on the welfare of children (Gruber, 2004), marital conflict (Stevenson and Wolfers, 2006), and women’s labor supply decisions (Fernández and Wong, 2014b; Grey, 1998; Peters, 1986; Stevenson, 2008). Unilateral divorce may also have important effects on household savings and investments. Stevenson (2007) evaluates the impact of divorce on marriage-specific investment such as the purchase of a house, showing that unilateral divorce tends to decrease such investments. Voena (2015) estimates the empirical relationship between divorce, married women's labor force participation, and household savings. Both papers show that propertydivision laws mediate the impact of unilateral divorce on the inter-temporal behavior of married couples.

Changes in exposure to divorce risk across cohorts have also been shown to impact investments. In particular, Fernández and Wong (2014a) use a dynamic quantitative approach to understand the differences in labor supply and household savings between the 1935 and 1955 cohorts, demonstrating that increases in divorce risk explain a substantial component of the observed changes for both married and divorced women under the age of 60 .

This chapter contributes to our understanding of women's later-life labor force participation (and the impacts of unilateral divorce) by using the widespread changes in divorce laws occurring from the late 1960s to the 1980s as a quasi-experiment to assess the importance of marital history on women's outcomes between ages 50 and 74. We first use data from the 1986 to 2008 waves of the Survey of Income and Program Participation (SIPP) to document the relationships between current marital status, past marital history, and current employment and retirement outcomes for women age 50 to 74, born 1911 to 1958 . We then exploit variation in laws governing divorce across states and over time to identify the causal relationship between the age at divorce and employment and retirement outcomes for older women.

We find that the spread of unilateral divorce was associated with cross-cohort differences in the probability of divorce over the lifecycle. We also show that past divorce has long run 
consequences for older women's marital, work, and retirement decisions, above and beyond the impact of past divorce on current marital status. For ever-divorced women, age at divorce is also an important determinant of these outcomes. Finally, we show that women who were exposed to unilateral divorce at later ages tended to get divorced later in life (conditional on ever getting divorced).

In addition, women exposed to unilateral divorce laws at older ages exhibit patterns of labor force participation and retirement later in life that differ by their ex ante probability of divorce. We find that for women who were less likely to expect a divorce, exposure to unilateral divorce at a later age significantly increases the probability of full-time employment later in life and reduces the probability of having ever collected social security. For women with a low likelihood of divorce, age of exposure to unilateral divorce does not affect full-time employment but is associated with an increased probability of having collected social security or retired. The pattern is stronger for white women and women with some college or less. For college-educated women, exposure to unilateral divorce at a later age increases the probability of full-time employment, irrespective of the divorce risk.

In exploring the mechanisms for the observed patterns of labor force participation, we find that, with the exception of women who were at low risk of divorce, later exposure to unilateral divorce is associated with increases in women's educational attainment after marriage. Furthermore, for all women, later exposure to unilateral divorce is associated with significantly lower level of retirement wealth but a significantly higher probability of having a 401k in one's own name. However, both effects are significantly larger for low divorce-risk women than for high divorce-risk women.

These findings are consistent with the literature suggesting that married women might invest more in their human capital (job experience, education) as a precaution against divorce when divorce risk increases. Women who were not likely to experience a divorce might have invested less in their own human capital as a hedge against future divorce. When this group was exposed to unilateral divorce later in life, and their divorce rate subsequently surged, they might have had to work more post-divorce and later in life to make up for lower earlier levels of human and financial capital accumulation. 


\section{Data}

We used the Survey of Income and Program Participation (SIPP) to explore the relationship between marital status and later-life labor force participation, drawing data from the panels that began in 1986 to 1988, 1990 to 1993, 1996, 2001, 2004, and 2008. These data provide key demographic information; details on respondents' current employment situations and assets; and retrospective information about respondents' educational attainment (including the dates degrees were received), employment, and marriages (including the year of marriage and the date and way a marriage ended, if applicable). ${ }^{1}$

Although many possible measures of labor force participation are of interest and provided in the SIPP, we focus our analysis on a variable indicating whether a woman reported working full-time at any point during her participation in the survey. We treat women employed full- and part-time differently because part-time workers may be partially retired or could have only a slight attachment to the labor force. Differently, we chose a broader measure of full-time work (at any point in the SIPP panel, as opposed to a single point in time) to capture all women who at any recent point had strong attachment to the labor force. In any case, our results are largely robust to using different measures of employment.

In most of the analysis, we restrict the sample to ever-married women ages 50 to 74. We further consider only women who provided information allowing us to identify their race, state of birth, age at marriage, marital status, employment status, urban location, and education at the time of their first SIPP interview. We drop all observations for which the status of a woman's first marriage could not be identified. The final sample contains 55,835 observations, including 38,313 never-divorced and 17,522 ever-divorced women.

Finally, while the sample sizes for all outcomes can vary due to item-specific nonresponse and non-response to one or more of the interviews throughout a SIPP panel,

\footnotetext{
${ }^{1}$ Kennedy and Ruggles (2014) argue that an increase in reporting errors in the retrospective marital history across SIPP surveys might lead to undercounting of divorces, thus overstating the decrease in divorce rates over the past few decades. That is, some of the women in our sample might be incorrectly classified as never divorced. This potential misclassification, if anything, might dampen the effect of marital history on current employment.
} 
sample sizes also vary because of changes in the content of the SIPP across waves. Summary statistics for the different samples are reported in Appendix Table 1.

\section{Changes in divorce rates by age and cohort}

Divorce rates were particularly low in the 1950s and early 1960s. They then rose sharply, doubling between the mid-1960s and the mid-1970s and peaking in the early to mid-1980s. Starting in 2005, the crude divorce rate has lingered around 3.6 divorces per thousand peoplethe lowest divorce rate since 1970 (see Figure 1 and related discussion in Stevenson and Wolfers, 2007). Although the issue has been somewhat contentious, a consensus has emerged in the economic literature that the shift from mutual consent divorce to unilateral divorce caused a short run increase in the divorce rate (Friedberg, 1998; Wolfers, 2007).

Figure 1 shows how women in our different cohorts experienced increases in divorce rates at different points in the lifecycle, as suggested by the relative timing of unilateral divorce legislation (to which we will return below). The figure describes the overall patterns in the share of women ever divorced by age and cohort. The shares are computed as a percentage of all women (panel A) and of ever-married women (panel B). The horizontal axis is age and different lines correspond to different cohorts. The patterns are similar for all women and ever-married women, with minor differences driven by the decline and postponement of marriage in the latest two cohorts. The graphs show that women in later cohorts are more likely to have ever divorced their spouses at any given age than women born in earlier cohorts. ${ }^{2}$

We also see that each cohort of interest exhibits a sharp increase in divorce at a different age. For the 1950 to 1959 cohort, this surge in divorce occurs prior to age 40 and the share of women ever divorced is essentially unchanged thereafter. For the next earliest cohort (women born 1940 to 1949), we see a sharp increase in divorce between age 40 and 45 . A similar increase can be seen for women born between 1930 and 1939 around age 50 and a smaller, albeit notable, increase in divorce can be found for the 1920 to 1929 cohort around age 60. Thus, the different cohorts exhibited similar increases in divorce in calendar time, but the increase in divorce occurred when the women were different ages.

\footnotetext{
${ }^{2}$ By definition, the share of women ever divorced should not decrease by age, and any small downward changes in Figure 1 are the result of sampling error.
} 
Differences in age at divorce are notable for several reasons. Most prominently, such differences can affect women’s marital status at later ages, as shown in Figure 2. For example, when observed in the SIPP between age 50 and 74, 55 percent of women who divorced before age 30 were currently married and 29 percent were currently divorced. For women who divorced in their forties, these proportions are reversed: 62 percent of these women were currently divorced and only 32 percent were currently married. Differences in age at divorce could also lead to changes in later-life employment and retirement choices, either because of differences in current marital status or for other reasons. The next section explores this possibility.

\section{The influence of current and past marital status on later-life outcomes}

\section{A. Descriptive regressions}

We use regression analysis to explore how both marital status and marital history relate to several employment outcomes for our sample of interest. Table 1 provides prima facie evidence that changes in patterns of marriage and divorce over time may explain a small but non-trivial share of the rise in later-life employment of women across birth cohorts.

The first column of Table 1 contains coefficients from a regression predicting labor force participation for women age 50 to 74 by birth cohort, including only age, state of birth, and cohort fixed effects. Column (2) adds in controls for other demographic characteristics, including education and race; columns (3) to (5) add in controls for marital history, including current marital status, whether a woman was ever married, divorced, or widowed, and age at first marriage and divorce for women who ever marry or ever divorce, respectively. When marital history controls are added, the increasing trend in employment across cohorts flattens somewhat, with coefficients falling by about 10 percent. The effect of marital history on employment is stronger for the cohorts of women born between 1930 and 1939, especially when labor force participation is measured at ages 50 to 59 or ages 60 to 64 (with coefficients dropping by about 20 percent and 15 percent, respectively, see results by age in Appendix Table A2). As shown in Figure 1, these are cohorts that experienced a surge in divorce around age 50.

In the remainder of this chapter, we focus on the impact of marital history and current marital status on later life outcomes, conditional on having ever been married. Our main sample, therefore, is restricted to ever-married women. Our baseline specification controls for birth year, 
state of birth, and age fixed effects; age at marriage; and race, education and urban location at the time of interview.

The results in Table 2 indicate that ignoring current marital status (column 1), everdivorced women are 7 percentage points more likely to have been employed full-time at some point during their participation in the SIPP. Results are similar if one instead focuses on whether a woman divorced prior to age 50 (column 3). Including indicators for both current and past marital status in the regression (column 2) reveals that both variables matter, though a woman's current marital status is a stronger predictor of current behavior. In particular, women who have ever divorced are 2 percentage points more likely than are other women to have worked during their SIPP panel, conditional on current marital status. Women who were divorced at the time they entered the SIPP panel were an additional 13 percentage points more likely to have worked (in total, these women are 15 percentage points more likely to have worked than a neverdivorced, currently married woman). This relationship holds if we instead consider measures of any employment (both part- and full-time, column 4), or full-time employment at a given point in time during the SIPP panel (column 5).

We additionally explored whether the relationship between employment and marital status varied for women in different demographic groups. Focusing on full-time employment, we found the relationship was relatively stable (see Table 3). Coefficients on both ever-divorce and current marital status tend to be similar for both whites (column 1) and non-whites (column 2), although the relationship between ever-divorce and employment is statistically significant only among white women. The relationships between the key independent variables and employment are also similar for women with a college education or more (column 3) and women with some college or less education (column 4). The exception is the coefficient for being currently separated, which is 8 percentage points higher for women with college or more education than for women with some college or less education. We also see similar patterns in the sample of women ages 60 to 69 (column 5) and ever-married women of a broader age range (50 to 74; column 2, Table 1).

We further examined whether marital status was associated with differences in two key, outcomes closely related to employment: whether a woman classified herself as ever having 
retired from a job and whether a woman collected social security (both measured at any point in the SIPP panel, see Table 4).

Overall, women who were ever divorced were about 2 percentage points more likely to have collected social security than never-divorced women (column 1). Considering both ever having been through a divorce and current marital status further suggests that the former is more important than the latter (column 2). The coefficient on the indicator for ever-divorce is statistically significant, while that on the indicator for currently being divorced is not. This pattern could result because many women who were ever divorced can collect social security based on their ex-spouses earnings, making them more likely to collect social security overall.

A different pattern emerges when one focuses on the sample of women who were older than 62 years, and thus eligible to collect social security based on their own work history (column 3). Within this group, the coefficient on ever-divorce is halved and current marital status is significantly related to collection of social security. Specifically, conditional on past marital status, currently divorced women are 3 percentage points less likely to have collected social security than currently married women who had previously divorced. This suggests that the relationship between marital status and social security receipt may differ within populations with different social security eligibility. ${ }^{3}$

Past and present marital status appear to relate differently to the propensity to consider oneself as having ever retired (columns 4 and 5). Ignoring the separate effect of current marital status (column 4), women who have ever been through a divorce are about 1 percentage point less likely to have ever retired than women who have not done so. But currently divorced women drive this relationship. Indeed, conditional on past marital status, currently divorced women are 8 percentage points less likely to have ever retired than other women.

For ever-divorced women, the age at which a divorce occurred is also an important predictor of later-life outcomes, even conditional on contemporaneous marital status. Table 5 reports regression results for our three outcomes within this sample. Women who divorced later

\footnotetext{
${ }^{3}$ See Maestas (this volume) for an analysis of social security eligibility on work and (joint) retirement of older women. See Iam and Tamborini (2012) for a study of the change in marital history and women's eligibility for Social Security marriage-based benefits at retirement across cohorts and its contribution to racial inequality at older ages.
} 
are more likely to be employed full-time. In particular, when we include in our regression a linear control for age at divorce, a 10-year increase in age at divorce is associated with a three percentage points increase in the propensity of a woman to work full-time when observed between ages 50 and 74 (column 1). However, about half of this effect can be explained by the impact of age at divorce on current marital status (column 2).

Further, including controls for age at divorce in ten-year bins (column 3), we find that, compared to women who divorced before 30, women who divorced in their thirties are 4 percentage points more likely to be employed full-time and women who divorced in their forties are 6 percentage points more likely to be employed full-time. Women who divorced in their fifties are the most likely to be working full-time. These women are about 10 percentage points more likely than women who divorced before 30 to work full-time when observed in the SIPP. Women who divorced after age 59 are also about 6 percentage points more likely than those who divorced before age 30 to work (however, our sample contains relatively few women who divorced after age 59 so some caution should be taken in interpreting this result).

Current marital status is an important factor for explaining these results (column 4). When controls for current status are added to the regression, the coefficients for divorcing in one's thirties, forties, or fifties decrease by about one-quarter or one-half. The coefficient on divorce at age 60 or older also decreases by an order of magnitude and becomes insignificant. Conditional on current marital status, age at divorce is also negatively associated with the probability a woman collects social security at any point in the panel, though the size of the effect is relatively small (columns 3 and 4); however, once current marital status is accounted for, age at marriage is not significantly related to the probability a woman has ever retired from a job (column 5 and 6).

\section{B. Changes in divorce legislation}

The associations laid out in the previous section, no matter how interesting, cannot be interpreted causally. To better understand how differences in marital history can cause differences in later-life labor force participation, we examine the relationship between divorce laws and our outcomes of interest. Changes in these laws over time and across states provide a 
quasi-experiment allowing us to measure plausibly exogenous variation in divorce risk across the lifecycle.

Divorce laws indicate the conditions under which a couple can divorce, each spouse's property rights over household assets, and guidelines for alimony and child support. Prior to the 1960s, most states allowed divorce only under mutual consent. Fault-based divorce law implied that divorce could be granted only under specific circumstances (for example, adultery, cruelty, or mental illness) and only under the consent of the party proved innocent (Weitzman, 1985). The late 1960s brought about the start of a shift in divorce laws from mutual consent to unilateral consent and from fault to no-fault grounds. ${ }^{4}$ Under no-fault divorce, a couple can simply agree that they cannot stay married due to irreconcilable differences or "irretrievable breakdown”. Though most states today have established no-fault, unilateral divorce laws, laws differ based on separation requirements (which may range from none to a one-year requirement) and on whether fault grounds shape the division of assets and spousal support. These variations have caused a small amount of variation in the definition of unilateral divorce in the literature.

We consider a state to have unilateral divorce if they allow no-fault marital dissolution and do not have a separation requirement. Spousal support and property division can still be atfault under our definition. This classification is very similar to others used in the literature (e.g. Gruber, 2004; Voena, 2015; Wolfers, 2006). ${ }^{5}$ As a robustness check we use a second classification that relaxes the no-separation requirement (that is, a state has unilateral divorce if and only if no-fault divorce is allowed). Under the second definition, some states are classified as allowing unilateral divorce at an earlier date and an additional eleven states are classified as ever allowing unilateral divorce. ${ }^{6}$ Our results are robust to using either of these definitions (but we only report findings based on our preferred definition).

We use a woman's state of birth to determine access to unilateral divorce.

\footnotetext{
${ }^{4}$ The late 1970s and 1980s also saw a shift in divorce laws that establish each spouse's property rights over household assets. It would also be interesting to investigate whether the changing property division legislation had an independent impact on employment but this is beyond the scope of this paper.

${ }^{5}$ In some cases, there is a one-year discrepancy between our definition and others in the literature. This is because we have chosen to classify a state as having unilateral divorce at the time the law becomes effective (for example, in Arizona the law passed May 1973 but went into effect on January 1974). See our Appendix for details.

${ }^{6}$ See Appendix Table 3. We also include a third definition that classifies a state as unilateral if alimony/assets are also assigned on no-fault grounds. See our Appendix for details.
} 
Identification is thus necessarily limited to women born in states where there was a change of legislation prior to the women's SIPP interviews. Using our preferred definition of unilateral divorce, the resulting sample contains 30,321 women (including 10,420 everdivorced and 19,901 never-divorced women). ${ }^{7}$

Our empirical strategy exploits cross-state, cross-cohort variation in access to unilateral divorce to identify the (pseudo) causal relationship between age at divorce and older women's outcome. Two stylized facts support this strategy.

First, as shown in Figure 3, exposure to unilateral divorce increased at different times across cohorts. This figure plots the share of women in our sample who were exposed to unilateral divorce at a given age, showing how the legal changes affected different cohorts at different points over their lifecycle and complementing the evidence on divorce rates in Figure 1. Less than 10 percent of women born between 1910 and 1919 were exposed to unilateral divorce before age 50. But by age 60, 60 percent had been exposed. Women in the 1920 to 1929 cohort experience minimal exposure until age 40 . But by age 60,80 percent of women in this cohort would have had access to unilateral divorce in their birth state. Similarly, women in the 1930 to 1939 cohorts experience the shift in their thirties and early forties and those born from 1940 to 1949 did so in their mid-twenties to mid-thirties. Of those in the most recent cohorts (born 1950 to 1959) 60 percent were exposed to unilateral divorce at age 20.

Second, as shown in Figure 4, there is a strong, positive correlation between the age at which divorce became unilateral and age at divorce among ever-divorced women. Thus, different cohorts exhibited similar increases in both divorce risk and divorce in calendar time, but this increase occurred when these women were at very different ages. We exploit this variation to study the relationship between the age divorce risk increased (that is, when unilateral divorce became available) and later outcomes.

\section{A more causal empirical specification}

We use OLS to explore the relationships of interest. The general version of the estimating equation is:

\footnotetext{
${ }^{7}$ Our alternative definition of unilateral divorce yields a sample of 49,806 women (16,174 ever-divorced and 13,632 never-divorced).
} 


$$
y_{i s c a}=\varphi_{s}+\eta_{c}+d_{a}+\alpha Z_{i}+\delta \text { Age at } \text { Unilateral }_{i s c}+\varepsilon_{i t s}
$$

where $y_{i s c a}$ is the outcome of interest (e.g., age at divorce, full-time employment, social security, or retirement) for person $i$, born in state $s$ and in cohort $c$, and observed in the SIPP at age $a$. $\varphi_{s}$ are state of birth dummies, $\eta_{\mathrm{c}}$ are year of birth dummies, $d_{a}$ are current age dummies, and $Z_{i}$ are individual-level covariates, including age at marriage or duration of marriage when unilateral divorce was introduced in a woman's birth state (depending on the specification), race (if applicable), education at interview (if applicable) and urban location at interview. Women born in states where unilateral divorce was never available are omitted from this analysis. ${ }^{8}$

The coefficient of greatest interest is that on the variable representing age when unilateral divorce became available determined based on state of birth, $\delta$. This coefficient represents the (pseudo) causal effect of having one's risk of divorce increase one year later in life. An increase in divorce risk later in life could lead to changes in outcomes for a number of reasons. The change could affect age at divorce, current marital status, or choices during marriage. It could also impact the process of marriage formation by altering the reservation quality of matching; however, for 84 percent women in our sample, marriage occurred before the law change, likely making this last mechanism less important.

The age at which unilateral divorce became available is associated with a marginally significant increase in the probability that a woman has ever been divorced, as shown in Table $6{ }^{9}$ For the entirety of our sample, we find that a 10-year increase in age at the legalization of unilateral divorce is associated with a 9 percentage point increase in the probability of ever divorcing. ${ }^{10}$ In column 2 we include controls for the age a woman gained access to unilateral divorce in ten-year bins, instead of a single, linear control. This reveals the relationship is highly non-linear and likely driven by the very early legalization of unilateral divorce in a small number of states. People who were exposed to unilateral divorce in their thirties, forties, or fifties have a 3 percentage-point higher probability of having ever been divorced relative to people who were

\footnotetext{
${ }^{8}$ We also omit nine women who were born in a state where unilateral divorce became available but were interviewed for the SIPP prior to that law change. These women lived in the small number of states that allowed unilateral divorce starting in 1987.

${ }^{9}$ The overall pattern of these results is similar when the outcome of interest is an indicator for having divorced by age 50 (see Appendix Table 4).

${ }^{10}$ The same results hold controlling for marriage duration, which is negatively correlated to the probability of having ever-divorced.
} 
exposed to unilateral divorce before age 30, though only the difference including women exposed in their thirties is significant. Women who were only exposed to unilateral divorce after age 59 have a significant, 5 percentage-point higher probability of being ever divorced, compared to women exposed before age 30 .

This finding may seem counterintuitive since people who were older when unilateral divorce was introduced are exposed to the increased divorce risk for fewer years. But this positive age effect is consistent with theoretical and empirical findings on the impact of unilateral divorce. As discussed in the literature, the passage of unilateral divorce was associated with a "pipeline" effect, causing marriages with the smallest surpluses to dissolve (Rasul, 2006; Wolfers, 2007). Our findings are consistent with older couples being more likely to have marriages characterized by very small surpluses because, for example, they are more likely to have older children and reduced gains from specialization. It is also possible that the shock introduced by the divorce revolution might have been larger or more salient for individuals who were socialized and lived most of their adult life in a conservative society where marriages should be saved at all costs and divorce was stigmatized.

A similar relationship between age at exposure to unilateral divorce and the probability of divorce holds for whites (column 3) and women age 60 to 69 (column 5) as that seen in the sample as a whole. However, the relationship is not significant for non-whites and is negative for women with some college or lower levels of educational attainment, which might be consistent with stricter or slower moving societal norms for the lesser educated. Differently, for collegeeducated women, age when unilateral divorce became available is strongly associated with a higher probability of ever-divorce.

Additionally, later exposure to unilateral divorce is associated with later age at divorce for ever-divorced women (see Table 7). For all such women, a ten-year increase in age when unilateral divorce was first allowed is associated with a 2.8 year delay in age at divorce (2.6 years controlling for age at marriage). Looking at subgroups, we find a stronger association within samples of white women, women with some college or less education, and women aged 60 to 69 . For these samples, a ten-year increase in the age at which unilateral divorce was introduced is associated with a four- to five-year delay in age at divorce. Consistent with the 
results in the previous table, we also find that age when unilateral divorce was implemented does not correlate with age at divorce for non-white women.

Having established these associations, we investigate the impact of the age when unilateral divorce was introduced on full-time employment later in life in Table 8. In addition to the entire population we split the sample based on an indicator of divorce risk. Specifically, we estimated a (probit) regression predicting whether a woman ever divorced using birth cohort, age at first marriage, education, race, and urban status at interview. We then estimate each woman's probability of divorce. Low divorce-risk women are defined as those in the lower quartile of the predicted probability distribution; high divorce-risk women are defined as those in the upper quartile of the predicted probability distribution.

We find that the association between later-life employment and the age unilateral divorce was introduced varies substantially depending on the sample considered. For all ever-married women together (the first panel of Table 8) and high divorce-risk women (third panel), full-time employment in later life is not significantly affected by the age when unilateral divorce became available. This pattern is consistent with a model in which women who face a higher divorce risk respond by remaining employed during marriage as a precaution, thus insuring themselves against a potential future loss of income due to divorce (Johnson and Skinner, 1986) and allowing them to retire earlier. In this case, delays in the age of exposure to unilateral divorce should have only small (or no) impacts on later life work decisions.

The age when unilateral divorce became available has very different implications for low divorce-risk women (the second panel). For this group, later exposure to unilateral divorce is associated with higher full-time employment at age 50 to 74. This is consistent with low divorcerisk women having to work remedially post-divorce and later in life if they are exposed to an increase in divorce risk when they are older. In other words, women facing a low divorce risk are less likely to have engaged in "precautionary working."

The size and significance of the coefficient is relatively consistent across specifications and does not depend on whether we control for age at marriage or the duration of marriage when unilateral divorce became available or whether we control for current marital status. The estimates imply that a ten-year delay in unilateral divorce legislation would be associated with a 
decline in the probability of full-time employment by 10 percentage points. Given that the fraction of women in our sample who were employed full time increased from 28 to 49 percent between the 1930 to 1939 and 1940 to 1949 cohorts, this is a (possibly too) large effect.

Endogeneity bias may be responsible for some of the magnitude of the effect. Although the age unilateral divorce was introduced is plausibly exogenous, the variable also likely affects some of the (endogenous) control variables - age at marriage, current marital status, education at interview - that have been shown to be important in predicting divorce (Bac, 2015; Rotz, forthcoming). Moreover, other factors discussed in this volume and elsewhere (for example, financial literacy, see Lusardi and Mitchell, 2008 and this volume, and changes in the normal retirement age and delay retirement credits, see Cribb et al., 2014 and Panis et al., 2002) are obviously also important determinants and potentially correlated with both our key variables.

Looking at other outcomes of interest (Table 9), we can see that for all ever married women, being older when unilateral divorce was introduced is associated with a lower probability of being employed (either full-time or part-time) at ages 50 to 74. Additionally, a later age when unilateral divorce was introduced is associated with an increase in both the probability of having ever collected social security or having ever retired at any point in the panel. This relationship also holds for the high divorce-risk group. The results for low divorcerisk, ever-married women (panel 2) show that being older at the introduction of unilateral divorce is also associated with an increase in employment (full time or part time) and with a lower probability of having collected social security within this sample.

We further consider how our results for employment vary by education and race in Table 10. The patterns for white women and women with some college or less educational attainment are similar to those in the overall sample of ever-married women with one exception. For lesseducated, high divorce-risk women, older age when unilateral divorce was introduced also decreases the probability of being employed full-time. For non-white and more-educated women, a ten-year increase in the age when unilateral divorce was introduced is associated with increases in full-time employment of about 3 and 6 percentage points, respectively. For women ages 60 to 69 , the coefficient on age when unilateral divorce was introduced is about 1 percentage point. 
Finally, Table 11 investigates some of the potential mechanisms for the relationship between age at exposure to unilateral divorce and labor force participation. In the sample of all ever-married women, older age at the introduction of unilateral divorce is associated with an increase in the probability of obtaining additional education after marriage and an increase in the probability of having one's own 401(k) or other retirement plan, but a decrease in the balance of reported retirement accounts. The findings are roughly similar within the low and high divorcerisk subsamples with one exception. For women with low divorce risk, later exposure to the unilateral laws does not affect the probability of having obtained additional education after their first marriage started. This suggests that some of the observed effects on labor force participation may be explained by changes in education and savings; however, the pattern of results suggests that other forces must also be at play.

\section{Conclusions}

Overall, we demonstrate that the spread of unilateral divorce was associated with crosscohort differences in the probability of divorce over the lifecycle. We also show that past divorce has long run consequences for older women's marital, work, and retirement decisions, above and beyond the impact of past divorce on current marital status. For ever-divorced women, the age at divorce is also an important determinant of these outcomes. Finally, we show that women who were exposed to unilateral divorce at later ages tended to get divorced later in life (conditional on ever getting divorced). They also exhibit different patterns of labor force participation and retirement at older ages.

For women with a low risk of divorce, an increase in divorce risk at a later age significantly increases the probability of full-time employment later in life (and reduces the probability of having ever collected social security). Additionally, later exposure to unilateral divorce is associated with a significantly lower level of retirement wealth. These findings suggest that ever-divorced women are working longer remedially. When they unexpectedly divorce at later ages, they are less likely to have engaged in precautionary human capital investment and have to work longer to increase their assets prior to retirement.

For all other women, a later exposure to divorce risk does not impact full-time employment after age 50 but is associated with investment in education post marriage. These 
women invest more in their own human capital within marriage, and seem to be insured against increasing exogenous divorce risk at later ages.

Our results suggest that changes in marital history and marital status, though not unilateral divorce law, can explain a non-trivial fraction of the increase in women's employment later in life. Controlling for age, race, education, and urban location, we estimate that women born in the early 1950s were about 19 percentage points more likely to be employed full-time at ages 50 to 74, compared to women born in the 1920s. Changes in the share of women ever married, ever divorced, or ever widowed explain about 11 percent of this difference. Likewise, changes in marital history can explain 12 percent of the 4 percentage-point difference in later-life employment between cohorts born in the 1920s and 1930s and 16 percent of the 14 percentagepoint difference between cohorts born in the 1920s and 1940s. However, we find no evidence that the timing of the large-scale introduction of unilateral divorce, which represents a substantial, one-time increase in divorce risk, plays a major role in understanding the increase in women's employment for the population as a whole. There is no statistically significant relationship between the timing of unilateral divorce legislation and later-life employment, on average. This null effect, however, masks substantial heterogeneity across women. We find that women facing a relatively low risk of divorce, especially women with a college degree, were more likely to work later in life if they were older when unilateral divorce laws were passed. Conversely, women with less education were less likely to work at ages 50-74 if they gained access to unilateral divorce later in life. 


\section{References}

Bac, Mehmet. 2015. “On the Selection Effects Under Consent and Unilateral Divorce,” American Law and Economics Review 17 (1): 43-86.

Couch, Kenneth A., Christopher R. Tamborini, Gayle L. Reznik, and John W. R. Phillips. 2011. “Impact of Divorce on Women’s Earnings and Retirement Over the Life Course.” Paper presented at the Conference on Unexpected Lifecycle Events and Economic Well-Being: The Roles of Job Loss, Disability, and Changing Family Structure. Federal Reserve Bank of San Francisco, CA.

Cribb, Jonathan, Carl Emmerson, and Gemma Tetlow. 2014. "How Does Increasing the Early Retirement Age for Women Affect the Labour Supply of Women and Their Husbands?” Netspar Discussion Paper 01/2014-003.

Fernández, Raquel, and Joyce C. Wong. 2014a. “Divorce Risk and Working Wives: A Quantitative Life-cycle Analysis of Female Labor Force Participation.” Economic Journal 124 (576): 319-58.

Fernández, Raquel and Joyce Wong. 2014b. "Unilateral Divorce, the Decreasing Gender Gap, and Married Women’s Labor Force Participation,” American Economic Review, 104(5): 342-47.

Friedberg, Leora. 1998. “Did Unilateral Divorce Raise Divorce Rates? Evidence from Panel Data,” American Economic Review 88 (3): 608-27.

Goldin, Claudia and Lawrence F. Katz. 2016. "Women Working Longer: Facts and Some Explanations.” NBER Working Paper No. 22607 (September).

Gray, Jeffrey. 1998. "Divorce-law Changes, Household Bargaining and Female Labor Supply,” American Economic Review 88 (3): 628-42.

Greene, W.H., and A.O. Quester. 1982. “Divorce Risk and Wives’ Labor Supply Behavior,” Social Science Quarterly 63 (1): 16-27.

Gruber, Jonathan. 2004. “Is Making Divorce Easier Bad for Children? The Long-run Implications of Unilateral Divorce,” Journal of Labor Economics 22 (4): 799-833.

Holden, Karen, and Fontes, Angela. 2009 “Economic Security in Retirement,” Journal of Women, Politics \& Policy 30 (2): 173-97. 
Iams, Howard M., and Christopher R. Tamborini. 2012. "The Implications of Marital History Change on Women's Eligibility for Social Security Wife and Widow Benefits, 1990-2009,” Social Security Bulletin 72 (2): 23-38.

Johnson W.R., and J. Skinner. 1986. “Labor Supply and Marital Separation,” American Economic Review 76 (3): 455-69.

Kennedy, Sheela and Steven Ruggles. 2014. "Breaking Up is Hard to Count: The Rise of Divorce in the United States, 1980-2010,” Demography 51(2): 587-98.

Lusardi, Annamaria, and Olivia S. Mitchell. 2016. “Older Women’s Labor Market Attachment, Retirement Planning, and Household Debt.” NBER Working Paper No. 22606, September.

Lusardi, Annamaria, and Olivia S. Mitchell. 2008. "Planning and Financial Literacy: How Do Women Fare?,” American Economic Review 98 (2): 413-17.

Maestas, Nicole. 2016. “The Return to Work and Women’s Employment Decisions.” Paper presented at the Women Working Longer Conference, Cambridge MA, May 21-22.

Munnell, Alicia. 2004. “Why Are So Many Older Women Poor?” Just the Facts on Retirement Issues (April) Just the Facts 10, Center for Retirement Research, Boston College.

Panis, Constantijn, Michael Hurd, David Loughran, Julie Zissimopoulos, Steven Haider, and Patricia St. Clair. 2002. “The Effects of Changing Social Security Administration’s Early Retirement Age and the Normal Retirement Age.” Santa Monica, CA: RAND.

Rasul, Imran. 2006. “Marriage Markets and Divorce Laws.” Journal of Law, Economics, and Organization 22 (1): 30-69.

Rotz, Dana. Forthcoming. “Why Have Divorce Rates Fallen? The Role of Women’s Age at Marriage," Journal of Human Resources.

Stevenson, Betsey. 2007. “The Impact of Divorce Laws on Marriage-Specific Capital,” Journal of Labor Economics 25 (1): 75-94.

Stevenson, Betsey. 2008. “Divorce Law and Women’s Labor Supply,” Journal of Empirical Legal Studies 5 (4): 853-73.

Stevenson, Betsey, and Justin Wolfers. 2006. "Bargaining in the Shadow of the Law: Divorce Laws and Family Distress,” Quarterly Journal of Economics 121 (1): 267-88. 
Stevenson, Betsey, and Justin Wolfers. 2007. "Marriage and Divorce: Changes and Their Driving Forces,” Journal of Economic Perspectives 21 (2): 27-52.

Tamborini, Christopher R., Howard M. Iams, and Kevin Whitman. 2009. "Marital Histories, Race, and Social Security Spouse and Widow Benefit Eligibility in the United States," Research on Aging 31 (5): 577-605.

Tamborini, Christopher R., and Kevin Whitman. 2007. "Women, Marriage, and Social Security Benefits: Revisited,” Social Security Bulletin 67 (4): 1-20.

Ulker, Aydogan. 2009. "Wealth Holdings and Portfolio Allocation of the Elderly: The Role of Marital History,” Journal of Family and Economic Issues 30 (1): 90-108.

Vespa, Jonathan, and Matthew A. Painter II. 2011. "Cohabitation History, Marriage, and Wealth Accumulation,” Demography 48 (3): 983-1004.

Voena, Alessandra. 2015. "Your, Mine and Ours: Do Divorce Laws Affect the Inter-temporal Behavior of Married Couples?,” American Economic Review 105 (8): 2295-332

Wilmoth, Janet, and Gregor Koso. 2002. "Does Marital History Matter? Marital Status and Wealth Outcomes Among Preretirement Adults.” Journal of Marriage and Family 64 (1): 254-68.

Weitzman, Lenore. 1985. The Divorce Revolution. Free Press; Collier Macmillan.

Wolfers, Justin. 2007. "Did Unilateral Divorce Laws Raise Divorce Rates? A Reconciliation and New Results,” American Economic Review 96 (5): 1802-1820.

Zagorsky, Jay L. 2005. “Marriage and Divorce’s Impact on Wealth,” Journal of Sociology 41 (4): 406-24.

Zissimopoulos, Julie, Benjamin Karney, and Amy Rauer. 2008. "Marital Histories and Economic Well-Being.” Michigan Retirement Research Center Research Paper No. WP 180. 


\section{Appendix: Timing of divorce law reforms}

Note that in the descriptions below, "fully unilateral” means meeting all criteria, including nofault alimony and having no separation requirement. "Unilateral" means that the state was not no-fault for alimony and/or assets.

\section{ALASKA}

Alaska became a no-fault state in 1935. Its first unilateral law was passed in 1962 and went into effect in 1963. The state became no-fault for alimony and asset division in 1974.

\section{ALABAMA}

Alabama became fully no-fault in 1971 (alimony and asset division included.)

\section{ARKANSAS}

Became no-fault in 1937 with a three-year mutually agreed upon separation requirement, and unilateral divorce allowed in 1979. The unilateral law had an 18-month separation requirement, and was no-fault for alimony/asset division.

\section{ARIZONA}

Arizona became fully no-fault (alimony included) with a law passed in 1973, which was implemented beginning in 1974.

\section{CALIFORNIA}

California passed a fully unilateral law (alimony included) in 1969, which went into effect in 1970.

\section{COLORADO}

Colorado introduced fully unilateral divorce with a law passed in 1971, effective starting 1972.

\section{CONNECTICUT}

Unilateral law passed in 1973 with no separation requirement.

\section{DELAWARE}

Unilateral with six-month separation requirement in 1968, where couples also had to show that the marriage had been irretrievably broken for two years prior to the divorce. Became no-fault for alimony in 1979 (passed 1978) but still had a separation requirement.

\section{DISTRICT OF COLUMBIA}

Unilateral law passed in 1977. There was a six-month separation requirement if mutually agreed upon or a twelve-month separation requirement if contested. 


\section{FLORIDA}

Introduced unilateral divorce with no separation requirement in 1971. Went no-fault for alimony in 1978.

\section{GEORGIA}

Introduced unilateral divorce with no separation requirement in 1973.

\section{HAWAII}

Introduced fully unilateral divorce in 1972.

\section{IOWA}

Iowa introduced unilateral divorce with no separation requirement in 1970, and without fault for alimony in 1972.

\section{IDAHO}

Idaho introduced unilateral divorce with no separation requirement in 1971, and for alimony in 1990.

\section{ILLINOIS}

Illinois became no-fault in 1984, with a law initially passed in 1983. The state had a two-year separation requirement and was no-fault for alimony.

\section{INDIANA}

Indiana introduced fully unilateral divorce in 1973.

\section{KANSAS}

Kansas introduced unilateral divorce in 1969 and no-fault for alimony in 1990.

\section{KENTUCKY}

Kentucky introduced unilateral divorce in 1972 and no-fault for alimony in 1987.

\section{LOUISIANA}

We are omitting Louisiana. There was little reliable and consistent information to be found on its historical divorce laws. This state allows covenant marriages, which only allow mutual consent or fault-based divorce. This is consistent with much of the literature.

\section{MASSACHUSETTS}

Massachusetts introduced unilateral divorce in 1975. 
MARYLAND

Allowed divorce after five-year separation in 1937, but was not unilateral. This was shortened to three years in 1969. The state introduced unilateral divorce with a two-year separation requirement in 1983.

\section{MAINE}

Introduced unilateral divorce in 1973, and added no-fault alimony in 1985.

\section{MICHIGAN}

Introduced unilateral divorce with no separation requirement in 1972.

\section{MINNESOTA}

Introduced fully unilateral divorce in 1974.

\section{MISSOURI}

Introduced unilateral divorce in 1973.

\section{MISSISSIPPI}

Mississippi added no-fault provisions to its grounds for divorce in 1976, but did not allow unilateral divorce. This was expanded upon in 1978 by adding no-fault alimony, but the state remains non-unilateral.

\section{MONTANA}

Montana added no-fault provisions to its allowed grounds for divorce in 1973. It introduced fully unilateral divorce, no-fault alimony included, in 1975.

\section{NORTH CAROLINA}

We omit North Carolina. This state only allowed divorce on grounds of separation (originally 10 years, shortened to 1 year in 1965) and adultery, and not on other traditional grounds such as cruelty, neglect to provide, and desertion.

\section{NORTH DAKOTA}

North Dakota introduced fully unilateral divorce in 1971.

\section{NEBRASKA}

Nebraska introduced fully unilateral divorce in 1972.

\section{NEW HAMPSHIRE}

New Hampshire introduced unilateral divorce in 1971. 


\section{NEW JERSEY}

New Jersey introduced unilateral divorce in 1971 with an 18-month separation requirement.

\section{NEW MEXICO}

New Mexico became no-fault in 1933, and unilateral in 1973. The state then became no-fault for alimony in 1976.

\section{NEVADA}

Nevada had loose divorce laws preceding the no-fault revolution but was not fully unilateral until 1973.

\section{NEW YORK}

New York is a fault state for divorce. Reforms in 1966 and 1967 only served to expand the list of allowed fault grounds for divorce.

\section{OHIO}

Ohio introduced unilateral divorce with a one-year separation requirement in 1974.

\section{OKLAHOMA}

Oklahoma was a unilateral state as early as 1953, and became no-fault for alimony in 1975.

\section{OREGON}

Oregon introduced fully unilateral divorce in 1973.

\section{PENNSYLVANIA}

Pennsylvania introduced unilateral divorce with some noteworthy restrictions in 1980. There was a three-year separation requirement, and if the divorce was contested, the court had to rule the marriage was broken in order for the divorce to be completed immediately. If the court did not rule that the marriage was broken, the judge had the authority to assign counseling before effectively ending the marriage. In practice, this appears to have allowed unilateral divorce.

\section{RHODE ISLAND}

Rhode Island introduced unilateral divorce in 1976.

\section{SOUTH CAROLINA}

South Carolina introduced unilateral divorce with a three-year separation requirement in 1969. This requirement was shortened to one year in 1979.

\section{SOUTH DAKOTA}

South Dakota introduced unilateral divorce in 1985. 


\section{TENNESSEE}

Tennessee introduced unilateral divorce in 1977 with a separation requirement that varied upon whether the couple had children (minimum two years).

\section{TEXAS}

Texas introduced unilateral divorce in 1970.

UTAH

Utah introduced unilateral divorce in 1987.

\section{VIRGINIA}

Virginia introduced unilateral divorce in 1960 with a varying separation requirement (minimum six months).

\section{VERMONT}

Vermont introduced unilateral divorce in 1969 with a six-month separation requirement.

WASHINGTON

Washington introduced fully unilateral divorce in 1973.

WISCONSIN

Wisconsin introduced unilateral divorce with a one-year separation requirement in 1978.

\section{WEST VIRGINIA}

West Virginia introduced unilateral divorce with a two-year separation requirement in 1977, which has since been reduced to one year.

\section{WYOMING}

Wyoming introduced unilateral divorce in 1977. 
Figure 1: Change in Incidence of Divorce, Age Profiles by Cohort

\section{Share of ever divorced women as a percentage of}
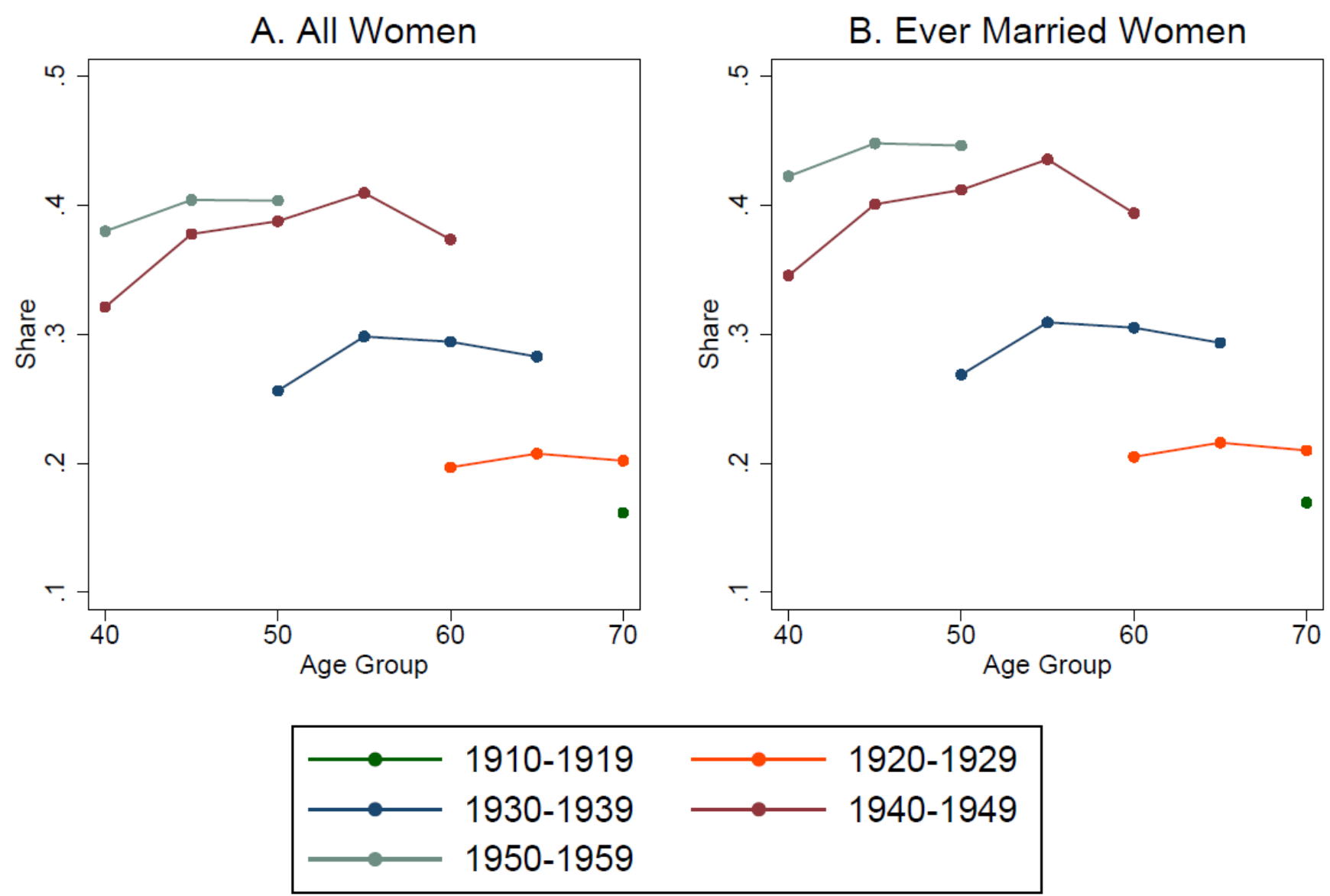

Source: Women ages 40 to 74 at first interview in the SIPP, 1986-2008 Panels. 
Figure 2: Age at Divorce and Current Marital Status (Ever-Divorced Women)

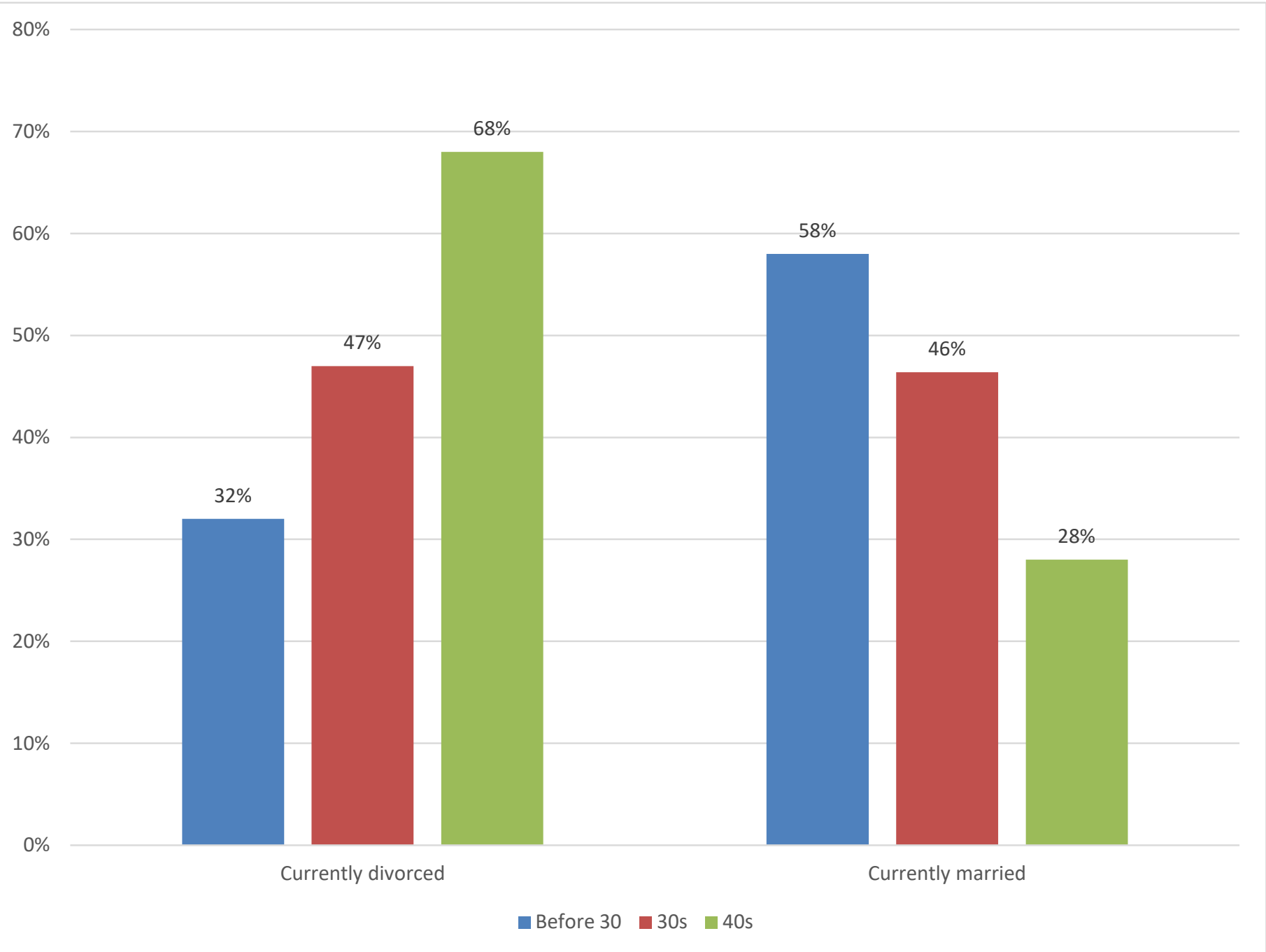

Source: Ever-divorced women ages 50 to 74 at first interview in the SIPP, 1986-2008 Panels. 
Figure 3: Exposure to Unilateral Divorce over the Life-cycle by Cohort (All Women)

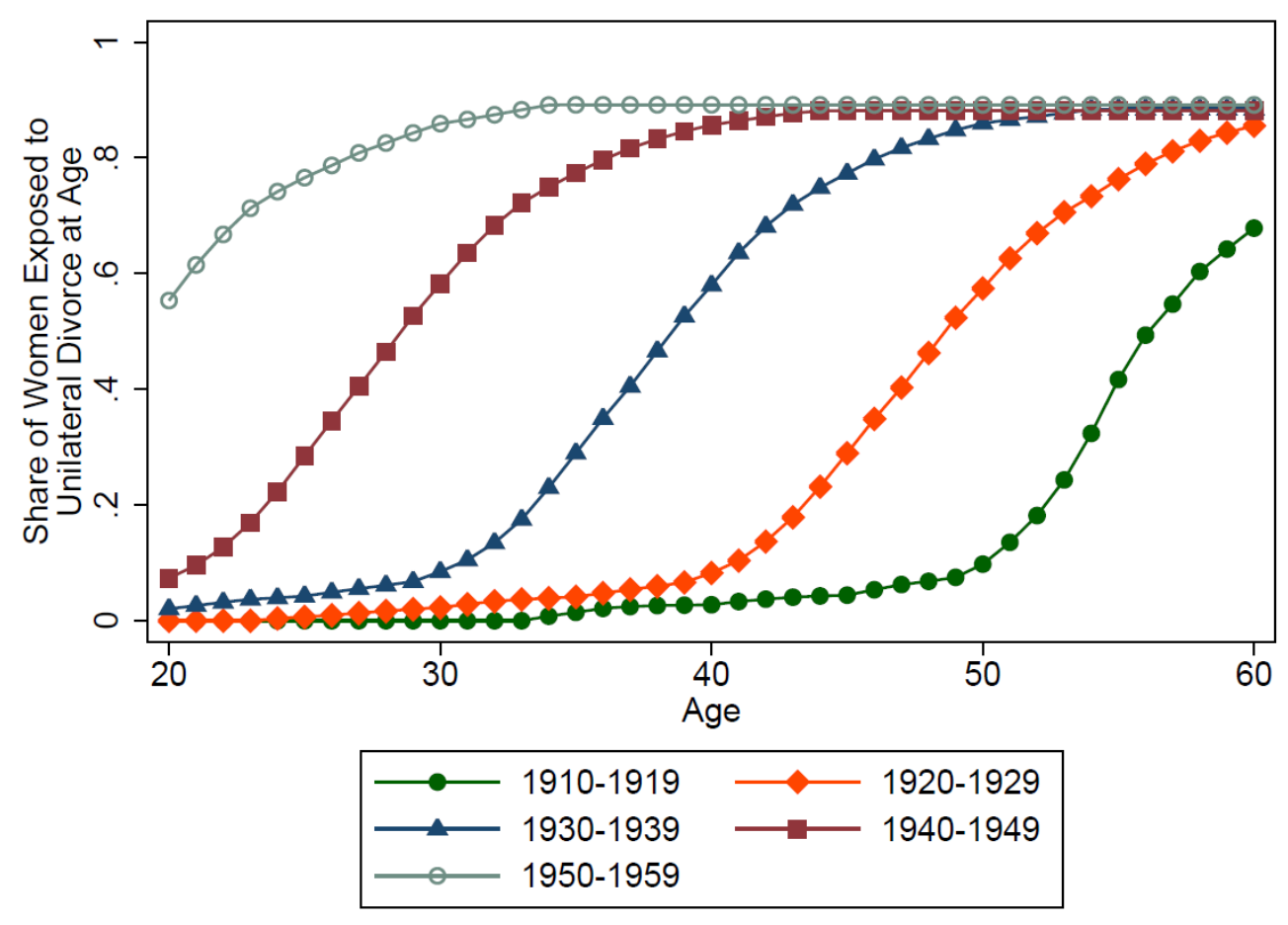

Source: Women ages 50 to 74 at first interview in the SIPP, 1986-2008 Panels. 
Figure 4: Age at Divorce and Age Unilateral Divorce Introduced (Ever-Divorced Women)

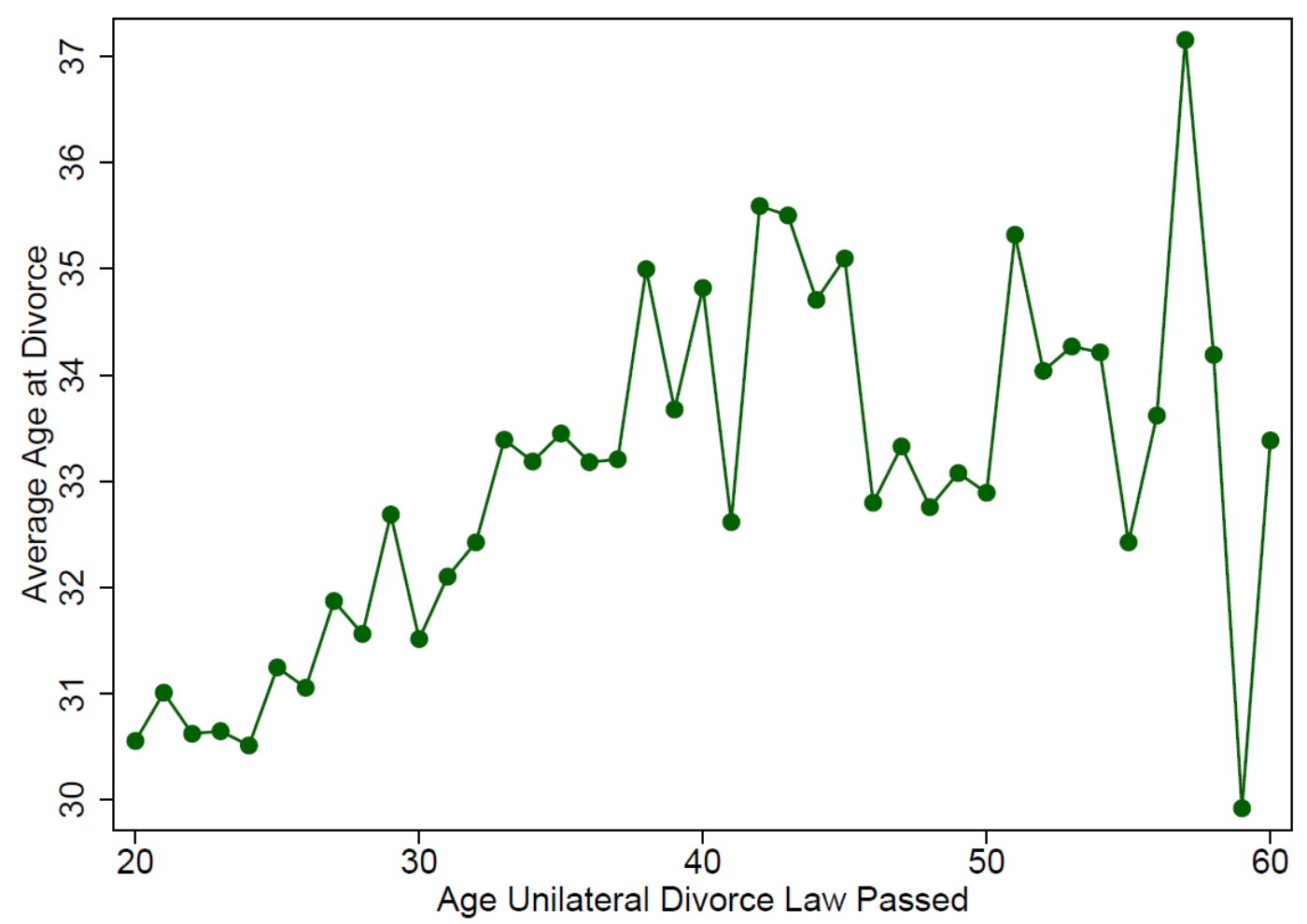

Source: Ever-divorced women ages 50 to 74 at first interview in the SIPP, 1986-2008 Panels.

Notes: Age when unilateral divorce became available is determined based on state of birth. Average age at divorce is computed conditional on having ever divorced. Women born in states where unilateral divorce was never available are omitted from this analysis. 
Table 1: Trends in Employment for Women Age 50-74 (All Marital Statuses)

\begin{tabular}{|c|c|c|c|c|c|}
\hline \multirow{2}{*}{ Cohort (1920-1924 omitted) } & \multicolumn{5}{|c|}{ Employed full time at any point in SIPP panel } \\
\hline & & & & & \\
\hline $1925-1929$ & $\begin{array}{c}0.0176 * * * \\
(0.00511)\end{array}$ & $\begin{array}{c}0.00573 \\
(0.00513)\end{array}$ & $\begin{array}{c}0.00336 \\
(0.00514)\end{array}$ & $\begin{array}{c}0.00228 \\
(0.00513)\end{array}$ & $\begin{array}{c}0.00265 \\
(0.00516)\end{array}$ \\
\hline $1930-1934$ & $\begin{array}{c}0.0400 * * * \\
(0.00536)\end{array}$ & $\begin{array}{c}0.0209 * * * \\
(0.00539)\end{array}$ & $\begin{array}{r}0.0174 * * * \\
(0.00540)\end{array}$ & $\begin{array}{c}0.0144 * * * \\
(0.00539)\end{array}$ & $\begin{array}{c}0.0148 * * * \\
(0.00542)\end{array}$ \\
\hline $1935-1939$ & $\begin{array}{c}0.0990 * * * \\
(0.00575)\end{array}$ & $\begin{array}{c}0.0589 * * * \\
(0.00577)\end{array}$ & $\begin{array}{c}0.0499 * * * \\
(0.00579)\end{array}$ & $\begin{array}{c}0.0457 * * * \\
(0.00578)\end{array}$ & $\begin{array}{c}0.0466^{* * *} * \\
(0.00581)\end{array}$ \\
\hline $1940-1944$ & $\begin{array}{l}0.169 * * * \\
(0.00655)\end{array}$ & $\begin{array}{l}0.112 * * * \\
(0.00677)\end{array}$ & $\begin{array}{r}0.0975 * * * \\
(0.00682)\end{array}$ & $\begin{array}{c}0.0926 * * * \\
(0.00681)\end{array}$ & $\begin{array}{c}0.0935 * * * \\
(0.00683)\end{array}$ \\
\hline $1945-1949$ & $\begin{array}{l}0.228^{* * *} \\
(0.00756)\end{array}$ & $\begin{array}{l}0.159 * * * \\
(0.00793)\end{array}$ & $\begin{array}{l}0.140 * * * \\
(0.00800)\end{array}$ & $\begin{array}{l}0.134^{* * *} \\
(0.00799)\end{array}$ & $\begin{array}{l}0.135 * * * \\
(0.00802)\end{array}$ \\
\hline $1950-1954$ & $\begin{array}{l}0.268 * * * \\
(0.00865)\end{array}$ & $\begin{array}{l}0.192 * * * \\
(0.00909)\end{array}$ & $\begin{array}{c}0.170^{* * *} \\
(0.00917)\end{array}$ & $\begin{array}{l}0.164^{* * *} \\
(0.00917)\end{array}$ & $\begin{array}{l}0.164 * * * \\
(0.00920)\end{array}$ \\
\hline Ever married & & & $\begin{array}{c}-0.0787 * * * \\
(0.00895)\end{array}$ & $\begin{array}{l}-0.0136 \\
(0.0579)\end{array}$ & $\begin{array}{l}-0.0290 \\
(0.0599)\end{array}$ \\
\hline Ever divorced & & & $\begin{array}{c}0.0758 * * * \\
(0.00420)\end{array}$ & $\begin{array}{c}0.0190 * * * \\
(0.00510)\end{array}$ & $\begin{array}{c}-0.0313^{* *} \\
(0.0128)\end{array}$ \\
\hline Ever widowed & & & $\begin{array}{r}0.0278 * * * \\
(0.00447)\end{array}$ & $\begin{array}{c}-0.00890 \\
(0.00905)\end{array}$ & $\begin{array}{c}0.000610 \\
(0.00983)\end{array}$ \\
\hline Currently married & & & & $\begin{array}{l}-0.0717 \\
(0.0577)\end{array}$ & $\begin{array}{c}-0.0878 \\
(0.0592)\end{array}$ \\
\hline Currently divorced & & & & $\begin{array}{c}0.0628 \\
(0.0580)\end{array}$ & $\begin{array}{c}0.0338 \\
(0.0595)\end{array}$ \\
\hline Currently separated & & & & $\begin{array}{c}-0.0513 \\
(0.0596)\end{array}$ & $\begin{array}{c}-0.0675 \\
(0.0611)\end{array}$ \\
\hline Currently widowed & & & & $\begin{array}{l}-0.00699 \\
(0.0583)\end{array}$ & $\begin{array}{c}-0.0303 \\
(0.0598)\end{array}$ \\
\hline $\begin{array}{l}\text { Ever married } \times \text { age at first } \\
\text { marriage }\end{array}$ & & & & & $\begin{array}{l}0.00135^{* * * *} \\
(0.000342)\end{array}$ \\
\hline $\begin{array}{l}\text { Ever divorced } \times \text { age at first } \\
\text { divorce }\end{array}$ & & & & & $\begin{array}{l}0.00174 * * * \\
(0.000371)\end{array}$ \\
\hline Other demographic controls & No & Yes & Yes & Yes & Yes \\
\hline Observations & 56,866 & 54,160 & 53,673 & 53,673 & 53,236 \\
\hline$R$-squared & 0.20 & 0.23 & 0.24 & 0.24 & 0.24 \\
\hline
\end{tabular}

Source: Women ages 50 to 74 at first interview in the SIPP, 1986-2008 Panels.

Notes: All columns control for age fixed effects. Columns two to five additionally control for race (white, black, Hispanic, other race), education at interview (less than high school, high school, some college, college or more), and urban location at interview. Omitted categories: never married, cohort born 1920-1924. Robust standard errors in parentheses.

$* / * * / * * *$ Significantly different from zero at the $0.10 / 0.05 / 0.01$ level, two tailed test. 
Table 2: Marital Status and Later-Life Employment - Ever-Married Women

\begin{tabular}{|c|c|c|c|c|c|}
\hline \multirow[b]{2}{*}{ Ever divorced } & \multicolumn{3}{|c|}{ Employed full time at any point in panel } & \multirow{2}{*}{$\begin{array}{c}\text { Employed at any } \\
\text { point in panel } \\
0.0172^{* * *} \\
(0.00502)\end{array}$} & \multirow{2}{*}{$\begin{array}{c}\text { Employed full time } \\
\text { in first panel month } \\
\\
0.0159^{* * *} \\
(0.00480)\end{array}$} \\
\hline & $\begin{array}{c}0.0740 * * * \\
(0.00406)\end{array}$ & $\begin{array}{c}0.0202 * * * \\
(0.00491)\end{array}$ & & & \\
\hline Ever widowed & $\begin{array}{l}0.0277 * * * \\
(0.00419)\end{array}$ & $\begin{array}{l}-0.00590 \\
(0.00835)\end{array}$ & & $\begin{array}{l}-0.00826 \\
(0.00909)\end{array}$ & $\begin{array}{l}-0.00479 \\
(0.00806)\end{array}$ \\
\hline Currently divorced & & $\begin{array}{l}0.126 * * * \\
(0.00671)\end{array}$ & & $\begin{array}{c}0.0944 * * * \\
(0.00653)\end{array}$ & $\begin{array}{l}0.134^{* * *} \\
(0.00674)\end{array}$ \\
\hline Currently widowed & & $\begin{array}{l}0.0586 * * * \\
(0.00893)\end{array}$ & & $\begin{array}{c}0.0586 * * * \\
(0.00988)\end{array}$ & $\begin{array}{c}0.0548 * * * \\
(0.00858)\end{array}$ \\
\hline Currently separated & & $\begin{array}{l}0.00793 \\
(0.0166)\end{array}$ & & $\begin{array}{c}-0.0368 * * \\
(0.0166)\end{array}$ & $\begin{array}{c}0.0162 \\
(0.0161)\end{array}$ \\
\hline Divorced by 50 & & & $\begin{array}{c}0.0762 * * * \\
(0.00439)\end{array}$ & & \\
\hline Widowed by 50 & & & $\begin{array}{c}0.0474 * * * \\
(0.00701)\end{array}$ & & \\
\hline Age at marriage & $\begin{array}{l}0.00194 * * * \\
(0.000315)\end{array}$ & $\begin{array}{c}0.00153 * * * \\
(0.000315)\end{array}$ & $\begin{array}{l}0.00213^{* * *} \\
(0.000352)\end{array}$ & $\begin{array}{c}0.000897 * * * \\
(0.000328)\end{array}$ & $\begin{array}{c}0.000788 * * * \\
(0.000305)\end{array}$ \\
\hline Observations & 55,835 & 55,835 & 49,242 & 55,835 & 55,835 \\
\hline$R$-squared & 0.260 & 0.266 & 0.252 & 0.289 & 0.213 \\
\hline
\end{tabular}

Source: Ever-married women ages 50 to 74 at first interview in the SIPP, 1986-2008 Panels.

Notes: Regressions also control for birth year, state of birth, age fixed effects, race (white, black, Hispanic, other race), education at interview (less than high school, high school, some college, college or more), and urban location at interview. Omitted category for marital status is currently married. Robust standard errors in parentheses.

$* / * * / * * *$ Significantly different from zero at the $0.10 / 0.05 / 0.01$ level, two tailed test. 
Table 3: Marital Status and Later-Life Employment by Demographic Group (Ever-Married Women)

\begin{tabular}{|c|c|c|c|c|c|}
\hline & \multicolumn{5}{|c|}{ Employed full time at any point in panel } \\
\hline & White & Non-White & College+ & $\begin{array}{c}\text { Some College or } \\
\text { Less }\end{array}$ & $60-69$ \\
\hline Ever divorced & $\begin{array}{l}0.0206 * * * \\
(0.00567)\end{array}$ & $\begin{array}{c}0.0129 \\
(0.00989)\end{array}$ & $\begin{array}{c}0.0221 \\
(0.0135)\end{array}$ & $\begin{array}{l}0.0202 * * * \\
(0.00526)\end{array}$ & $\begin{array}{l}0.0172 * * \\
(0.00739)\end{array}$ \\
\hline Ever widowed & $\begin{array}{c}0.00428 \\
(0.00940)\end{array}$ & $\begin{array}{c}-0.0428^{* *} \\
(0.0180)\end{array}$ & $\begin{array}{l}-0.0138 \\
(0.0278)\end{array}$ & $\begin{array}{l}-0.00616 \\
(0.00874)\end{array}$ & $\begin{array}{l}0.00587 \\
(0.0115)\end{array}$ \\
\hline Currently divorced & $\begin{array}{l}0.141 * * * \\
(0.00791)\end{array}$ & $\begin{array}{c}0.0903^{* * *} \\
(0.0128)\end{array}$ & $\begin{array}{c}0.143 * * * \\
(0.0160)\end{array}$ & $\begin{array}{l}0.121 * * * \\
(0.00745)\end{array}$ & $\begin{array}{l}0.132^{* * *} \\
(0.0113)\end{array}$ \\
\hline Currently widowed & $\begin{array}{c}0.0621^{* * *} \\
(0.0102)\end{array}$ & $\begin{array}{c}0.0584^{* * * *} \\
(0.0187)\end{array}$ & $\begin{array}{c}0.0902^{* * * *} \\
(0.0305)\end{array}$ & $\begin{array}{l}0.0539 * * * \\
(0.00932)\end{array}$ & $\begin{array}{c}0.0432 * * * \\
(0.0125)\end{array}$ \\
\hline Currently separated & $\begin{array}{c}0.0204 \\
(0.0269)\end{array}$ & $\begin{array}{l}0.000137 \\
(0.0212)\end{array}$ & $\begin{array}{c}0.0854 * * \\
(0.0429)\end{array}$ & $\begin{array}{c}0.00173 \\
(0.0178)\end{array}$ & $\begin{array}{l}0.0529 * \\
(0.0278)\end{array}$ \\
\hline Age at marriage & $\begin{array}{c}0.00161 * * * \\
(0.000376)\end{array}$ & $\begin{array}{l}0.00147 * * \\
(0.000577)\end{array}$ & $\begin{array}{c}-0.000724 \\
(0.000781)\end{array}$ & $\begin{array}{c}0.00202^{* * * *} \\
(0.000344)\end{array}$ & $\begin{array}{c}0.00215^{* * * *} \\
(0.000484)\end{array}$ \\
\hline $\begin{array}{l}\text { Observations } \\
R \text {-squared }\end{array}$ & $\begin{array}{c}42,539 \\
0.267\end{array}$ & $\begin{array}{c}13,296 \\
0.272\end{array}$ & $\begin{array}{l}9,479 \\
0.275\end{array}$ & $\begin{array}{c}46,356 \\
0.248\end{array}$ & $\begin{array}{c}21,336 \\
0.124\end{array}$ \\
\hline
\end{tabular}

Source: Ever-married women ages 50 to 74 at first interview in the SIPP, 1986-2008 Panels.

Notes: Regressions also control for birth year, state of birth, age fixed effects, race if applicable (white, black, Hispanic, other race), education at interview if applicable (less than high school, high school, some college, college or more), and urban location at interview. Omitted category for marital status is currently married. Robust standard errors in parentheses.

$* / * * / * * *$ Significantly different from zero at the $0.10 / 0.05 / 0.01$ level, two tailed test. 
Table 4: Marital Status, Social Security and Retirement (Ever-Married Women)

\begin{tabular}{|c|c|c|c|c|c|}
\hline \multirow[b]{3}{*}{ Ever divorced } & \multicolumn{3}{|c|}{ Collected social security at any point in panel } & \multirow{2}{*}{\multicolumn{2}{|c|}{$\begin{array}{c}\text { Retired at any point in panel } \\
\text { All ever-married women }\end{array}$}} \\
\hline & \multicolumn{2}{|c|}{ All ever-married women } & \multirow{2}{*}{$\begin{array}{l}\text { Aged 62+ } \\
0.00815^{*} \\
(0.00419)\end{array}$} & & \\
\hline & $\begin{array}{l}0.0177^{* * *} \\
(0.00304)\end{array}$ & $\begin{array}{c}0.0194 * * * \\
(0.00370)\end{array}$ & & $\begin{array}{c}-0.00767 * * \\
(0.00384)\end{array}$ & $\begin{array}{c}0.0267 * * * \\
(0.00476)\end{array}$ \\
\hline Ever widowed & $\begin{array}{l}0.0504 * * * \\
(0.00349)\end{array}$ & $\begin{array}{l}0.0224 * * * \\
(0.00678)\end{array}$ & $\begin{array}{l}-0.000693 \\
(0.00697)\end{array}$ & $\begin{array}{c}0.00106 \\
(0.00448)\end{array}$ & $\begin{array}{l}0.0195 * * \\
(0.00871)\end{array}$ \\
\hline Currently divorced & & $\begin{array}{l}-0.00152 \\
(0.00524)\end{array}$ & $\begin{array}{c}-0.0255^{* * * *} \\
(0.00650)\end{array}$ & & $\begin{array}{c}-0.0807 * * * \\
(0.00624)\end{array}$ \\
\hline Currently widowed & & $\begin{array}{c}0.0359 * * * \\
(0.00735)\end{array}$ & $\begin{array}{c}0.00218 \\
(0.00724)\end{array}$ & & $\begin{array}{c}-0.0346 * * * \\
(0.00950)\end{array}$ \\
\hline Currently separated & & $\begin{array}{l}0.0365^{* *} \\
(0.0142)\end{array}$ & $\begin{array}{l}-0.0270 \\
(0.0179)\end{array}$ & & $\begin{array}{c}-0.0698 * * * \\
(0.0144)\end{array}$ \\
\hline Age at marriage & $\begin{array}{c}-0.000790 * * * \\
(0.000252)\end{array}$ & $\begin{array}{c}-0.000830^{* * *} \\
(0.000253)\end{array}$ & $\begin{array}{c}-0.00108^{* * * *} \\
(0.000289)\end{array}$ & $\begin{array}{c}0.000833 * * * \\
(0.000313)\end{array}$ & $\begin{array}{l}0.00111 * * * \\
(0.000313)\end{array}$ \\
\hline Observations & 55,835 & 55,835 & 24,958 & 55,835 & 55,835 \\
\hline$R$-squared & 0.623 & 0.623 & 0.086 & 0.358 & 0.360 \\
\hline
\end{tabular}

Source: Ever-married women ages 50 to 74 at first interview in the SIPP, 1986-2008 Panels.

Notes: Regressions also control for birth year, state of birth, age fixed effects, race if applicable (white, black, Hispanic, other races), education at interview if applicable (less than high school, high school, some college, college or more), and urban location at interview. Omitted category for marital status is currently married. Robust standard errors in parentheses.

$* / * * / * * *$ Significantly different from zero at the 0.10/0.05/0.01 level, two tailed test. 
Table 5: Divorce Timing and Later-Life Outcomes—Ever-Divorced Women

\begin{tabular}{|c|c|c|c|c|c|c|c|c|}
\hline \multirow[b]{2}{*}{ Ever widowed } & \multicolumn{4}{|c|}{ Employed full time at any point in panel } & \multicolumn{2}{|c|}{$\begin{array}{c}\text { Collected social security } \\
\text { at any point in panel }\end{array}$} & \multicolumn{2}{|c|}{$\begin{array}{c}\text { Retired at any point in } \\
\text { panel }\end{array}$} \\
\hline & $\begin{array}{l}-0.0116 \\
(0.00977)\end{array}$ & $\begin{array}{l}-0.0271 \\
(0.0196)\end{array}$ & $\begin{array}{l}-0.0130 \\
(0.00977)\end{array}$ & $\begin{array}{l}-0.0266 \\
(0.0196)\end{array}$ & $\begin{array}{c}0.0354^{* *} \\
(0.0162)\end{array}$ & $\begin{array}{c}0.0356 * * \\
(0.0162)\end{array}$ & $\begin{array}{l}-0.0108 \\
(0.0194)\end{array}$ & $\begin{array}{l}-0.0111 \\
(0.0194)\end{array}$ \\
\hline Currently divorced & & $\begin{array}{l}0.115^{* * *} \\
(0.00768)\end{array}$ & & $\begin{array}{l}0.116^{* * *} \\
(0.00767)\end{array}$ & $\begin{array}{c}0.00745 \\
(0.00598)\end{array}$ & $\begin{array}{c}0.00710 \\
(0.00598)\end{array}$ & $\begin{array}{c}-0.0799 * * * \\
(0.00708)\end{array}$ & $\begin{array}{r}-0.0798^{* * *} \\
(0.00706)\end{array}$ \\
\hline Currently widowed & & $\begin{array}{c}0.0746 * * * \\
(0.0211)\end{array}$ & & $\begin{array}{c}0.0738 * * * \\
(0.0211)\end{array}$ & $\begin{array}{c}0.0428 * * \\
(0.0176)\end{array}$ & $\begin{array}{c}0.0428 * * \\
(0.0176)\end{array}$ & $\begin{array}{c}-0.0220 \\
(0.0214)\end{array}$ & $\begin{array}{l}-0.0217 \\
(0.0214)\end{array}$ \\
\hline Currently separated & & $\begin{array}{c}0.0430 \\
(0.0307)\end{array}$ & & $\begin{array}{c}0.0434 \\
(0.0307)\end{array}$ & $\begin{array}{l}0.0511^{* *} \\
(0.0253)\end{array}$ & $\begin{array}{l}0.0511^{* *} \\
(0.0253)\end{array}$ & $\begin{array}{c}-0.0628 * * \\
(0.0251)\end{array}$ & $\begin{array}{c}-0.0629 * * \\
(0.0251)\end{array}$ \\
\hline Age at divorce & $\begin{array}{l}0.00318^{* * *} \\
(0.000375)\end{array}$ & $\begin{array}{l}0.00159 * * * \\
(0.000388)\end{array}$ & & & $\begin{array}{c}-0.000723^{* *} \\
(0.000304)\end{array}$ & & $\begin{array}{l}-0.000289 \\
(0.000372)\end{array}$ & \\
\hline Divorced in 30s & & & $\begin{array}{c}0.0407 * * * \\
(0.00828)\end{array}$ & $\begin{array}{c}0.0306 * * * \\
(0.00825)\end{array}$ & & $\begin{array}{l}-0.00845 \\
(0.00642)\end{array}$ & & $\begin{array}{l}-0.00791 \\
(0.00770)\end{array}$ \\
\hline Divorced in 40 s & & & $\begin{array}{c}0.0642 * * * \\
(0.00983)\end{array}$ & $\begin{array}{c}0.0347 * * * \\
(0.00995)\end{array}$ & & $\begin{array}{l}-0.0108 \\
(0.00766)\end{array}$ & & $\begin{array}{l}-0.00142 \\
(0.00923)\end{array}$ \\
\hline Divorced in 50 s & & & $\begin{array}{c}0.0962 * * * \\
(0.0148)\end{array}$ & $\begin{array}{c}0.0461 * * * \\
(0.0151)\end{array}$ & & $\begin{array}{c}-0.0300 * * * \\
(0.0115)\end{array}$ & & $\begin{array}{l}-0.0222 \\
(0.0147)\end{array}$ \\
\hline Divorced at age $60+$ & & & $\begin{array}{l}0.0635 * * \\
(0.0284)\end{array}$ & $\begin{array}{l}0.00602 \\
(0.0288)\end{array}$ & & $\begin{array}{l}-0.00223 \\
(0.0226)\end{array}$ & & $\begin{array}{l}0.00246 \\
(0.0309)\end{array}$ \\
\hline Age at marriage & $\begin{array}{l}0.00224 * * * \\
(0.000853)\end{array}$ & $\begin{array}{l}0.00179 * * \\
(0.000850)\end{array}$ & $\begin{array}{l}0.00256 * * * \\
(0.000843)\end{array}$ & $\begin{array}{l}0.00189 * * \\
(0.000840)\end{array}$ & $\begin{array}{l}-0.00102 \\
(0.000681)\end{array}$ & $\begin{array}{l}-0.00111 \\
(0.000675)\end{array}$ & $\begin{array}{c}0.00127 \\
(0.000815)\end{array}$ & $\begin{array}{c}0.00132 \\
(0.000807)\end{array}$ \\
\hline Observations & 17,054 & 17,054 & 17,054 & 17,054 & 17,054 & 17,054 & 17,054 & 17,054 \\
\hline$R$-squared & 0.247 & 0.258 & 0.247 & 0.258 & 0.556 & 0.556 & 0.350 & 0.350 \\
\hline
\end{tabular}

Source: Ever-divorced women ages 50 to 74 at first interview in the SIPP, 1986-2008 Panels.

Notes: Regressions also control for birth year, state of birth, age fixed effects, race (white, black, Hispanic, other race), education at interview (less than high school, high school, some college, college or more) and urban location at interview. Omitted categories: currently married, divorced before age 30. Robust standard errors in parentheses.

$* / * * / * * *$ Significantly different from zero at the $0.10 / 0.05 / 0.01$ level, two tailed test. 
Table 6: Effect of Age When Unilateral Divorce Became Available on Divorce Probability - Ever-Married Women

\begin{tabular}{|c|c|c|c|c|c|c|c|}
\hline & \multicolumn{7}{|c|}{ Indicator for Ever-Divorce } \\
\hline & \multicolumn{2}{|c|}{ All women } & White & Non-white & $\begin{array}{c}\text { College or } \\
\text { more }\end{array}$ & $\begin{array}{c}\text { Some college } \\
\text { or less }\end{array}$ & $60-69$ \\
\hline $\begin{array}{l}\text { Age when } \\
\text { unilateral divorce }\end{array}$ & \multirow{2}{*}{\multicolumn{2}{|c|}{$\begin{array}{l}0.00887 * \\
(0.00452)\end{array}$}} & $0.00945 *$ & -0.0130 & $0.0687^{* * *}$ & $-0.0156^{* * *}$ & $0.0141^{* * *}$ \\
\hline $\begin{array}{l}\text { introduced } \\
\text { Unilateral divorce } \\
\text { introduced: }\end{array}$ & & & $(0.00487)$ & $(0.0163)$ & $(0.00937)$ & $(0.00502)$ & $(0.000894)$ \\
\hline $30 s$ & & $\begin{array}{l}0.0254^{* *} \\
(0.0111)\end{array}$ & & & & & \\
\hline $40 s$ & & $\begin{array}{c}0.0307 \\
(0.0185)\end{array}$ & & & & & \\
\hline $50 \mathrm{~s}$ & & $\begin{array}{c}0.0249 \\
(0.0220)\end{array}$ & & & & & \\
\hline $60+$ & & $\begin{array}{l}0.0500^{*} \\
(0.0295)\end{array}$ & & & & & \\
\hline Age at marriage & $\begin{array}{l}-0.0141 * * * \\
(0.000456)\end{array}$ & $\begin{array}{l}-0.0141^{* * *} \\
(0.000457)\end{array}$ & $\begin{array}{l}-0.0147 * * * \\
(0.000475)\end{array}$ & $\begin{array}{l}-0.0123 * * * \\
(0.000631)\end{array}$ & $\begin{array}{c}-0.0144 * * * \\
(0.00153)\end{array}$ & $\begin{array}{l}-0.0140 * * * \\
(0.000471)\end{array}$ & $\begin{array}{r}-0.0121 * * * \\
(0.000673)\end{array}$ \\
\hline Observations & 30,321 & 30,321 & 23,001 & 7,320 & 5,050 & 25,271 & 11,357 \\
\hline$R$-squared & 0.086 & 0.086 & 0.093 & 0.081 & 0.084 & 0.091 & 0.076 \\
\hline
\end{tabular}

Source: Ever-married women ages 50 to 74 at first interview in the SIPP, 1986-2008 Panels.

Notes: The dependent variable is an indicator that equals one if ever divorced and zero otherwise. Age when unilateral divorce became available is determined based on state of birth. Regressions also control for birth year, state of birth, age fixed effects, race (if applicable; white, black, Hispanic, other race), education at interview (if applicable; less than high school, high school, some college, college or more), and urban location at interview. Omitted category for age when unilateral divorce was introduced is before age 30. Women born in states where unilateral divorce was never available are omitted from this analysis. Standard errors clustered by state of birth are reported in parentheses.

$* / * * / * * *$ Significantly different from zero at the $0.10 / 0.05 / 0.01$ level, two tailed test. 
Table 7: Effect of Age When Unilateral Divorce Became Available on Age at Divorce - Ever-Divorced Women

\begin{tabular}{|c|c|c|c|c|c|c|c|c|}
\hline & \multicolumn{8}{|c|}{ Age at Divorce } \\
\hline & \multicolumn{3}{|c|}{ All ever-divorced women } & White & Non-white & College+ & $\begin{array}{l}\text { Some } \\
\text { college }\end{array}$ & $60-69$ \\
\hline $\begin{array}{l}\text { Age when unilateral divorce } \\
\text { introduced }\end{array}$ & $\begin{array}{c}0.281 * * \\
(0.122)\end{array}$ & $\begin{array}{c}0.258^{* *} \\
(0.111)\end{array}$ & $\begin{array}{c}0.790 * * * \\
(0.134)\end{array}$ & $\begin{array}{c}0.443^{* * *} \\
(0.144)\end{array}$ & $\begin{array}{c}0.00457 \\
(0.337)\end{array}$ & $\begin{array}{c}0.174 \\
(0.208)\end{array}$ & $\begin{array}{c}0.484^{* * *} \\
(0.141)\end{array}$ & $\begin{array}{r}0.537 * * * \\
(0.0566)\end{array}$ \\
\hline Age at marriage & & $\begin{array}{l}0.967 * * * \\
(0.0215)\end{array}$ & & $\begin{array}{l}0.987 * * * \\
(0.0275)\end{array}$ & $\begin{array}{l}0.920 * * * \\
(0.0235)\end{array}$ & $\begin{array}{l}0.847 * * * \\
(0.0536)\end{array}$ & $\begin{array}{l}0.996 * * * \\
(0.0237)\end{array}$ & $\begin{array}{l}0.991 * * * \\
(0.0406)\end{array}$ \\
\hline $\begin{array}{l}\text { Marriage duration when } \\
\text { unilateral divorce introduced }\end{array}$ & & & $\begin{array}{l}0.694^{* * *} \\
(0.00995)\end{array}$ & & & & & \\
\hline Observations & 10,133 & 10,133 & 10,133 & 7,457 & 2,676 & 1,672 & 8,461 & 3,370 \\
\hline$R$-squared & 0.074 & 0.228 & 0.560 & 0.229 & 0.264 & 0.296 & 0.210 & 0.215 \\
\hline
\end{tabular}

Source: Ever divorced women ages 50 to 74 at first interview in the SIPP, 1986-2008 Panels.

Notes: Age when unilateral divorce became available is determined based on state of birth. Regressions also control for birth year, state of birth, age fixed effects, race (if applicable; white, black, Hispanic, other race), education at interview (if applicable; less than high school, high school, some college, college or more), and urban location at interview. Women born in states where unilateral divorce was never available are omitted from this analysis. Standard errors clustered by state of birth are reported in parentheses.

$* / * * / * * *$ Significantly different from zero at the $0.10 / 0.05 / 0.01$ level, two tailed test. 
Table 8: Effect of Age When Unilateral Divorce Became Available on Later-Life Employment - EverMarried Women

\begin{tabular}{|c|c|c|c|c|}
\hline \multirow{4}{*}{$\begin{array}{l}\text { Age when unilateral divorce } \\
\text { introduced } \\
\text { Age at marriage }\end{array}$} & \multicolumn{4}{|c|}{ Employed full time at any point in panel } \\
\hline & \multicolumn{4}{|c|}{ All ever-married } \\
\hline & $\begin{array}{l}-0.00226 \\
(0.00428)\end{array}$ & $\begin{array}{c}-0.00510 \\
(0.0042 ?)\end{array}$ & $\begin{array}{l}-0.00110 \\
(0.00412)\end{array}$ & $\begin{array}{l}-0.00541 \\
0.00412)\end{array}$ \\
\hline & $\begin{array}{l}0.000492 * \\
(0.000268)\end{array}$ & $\begin{array}{c}0.000953 * * * \\
(0.000286)\end{array}$ & & \\
\hline $\begin{array}{l}\text { Marriage duration when } \\
\text { unilateral divorce introduced }\end{array}$ & & & $\begin{array}{c}-0.000765 * * * \\
(0.000153)\end{array}$ & $\begin{array}{l}-0.000160 \\
(0.000144)\end{array}$ \\
\hline $\begin{array}{l}\text { Control for current marital } \\
\text { status }\end{array}$ & No & Yes & No & Yes \\
\hline Observations & 30,370 & 30,370 & 30,370 & 30,370 \\
\hline \multirow[t]{2}{*}{$R$-squared } & 0.251 & 0.262 & 0.251 & 0.261 \\
\hline & \multicolumn{4}{|c|}{ Low Divorce Risk } \\
\hline $\begin{array}{l}\text { Age when unilateral divorce } \\
\text { introduced }\end{array}$ & $0.106^{* * *}$ & $0.107 * * *$ & $0.108 * * *$ & $0.107 * * *$ \\
\hline & $(0.0263)$ & $(0.0264)$ & $(0.0262)$ & $(0.0263)$ \\
\hline Age at marriage & $\begin{array}{c}0.000172 \\
(0.000679)\end{array}$ & $\begin{array}{c}0.000493 \\
(0.000653)\end{array}$ & & \\
\hline $\begin{array}{l}\text { Marriage duration when } \\
\text { unilateral divorce introduced } \\
\text { Control for current marital }\end{array}$ & & & $\begin{array}{c}-0.000767 * * * \\
(0.000260)\end{array}$ & $\begin{array}{l}-0.000217 \\
(0.000242)\end{array}$ \\
\hline status & No & Yes & No & Yes \\
\hline Observations & 7,582 & 7,582 & 7,582 & 7,582 \\
\hline \multirow[t]{2}{*}{$R$-squared } & 0.246 & 0.256 & 0.247 & 0.256 \\
\hline & \multicolumn{4}{|c|}{ High Divorce Risk } \\
\hline $\begin{array}{l}\text { Age when unilateral divorce } \\
\text { introduced }\end{array}$ & $\begin{array}{l}0.00223 \\
(0.00488)\end{array}$ & $\begin{array}{l}-0.00142 \\
(0.00470)\end{array}$ & $\begin{array}{c}0.00177 \\
(0.00506)\end{array}$ & $\begin{array}{l}-0.00299 \\
(0.00485)\end{array}$ \\
\hline Age at marriage & $\begin{array}{c}0.00943 * * * \\
(0.00302)\end{array}$ & $\begin{array}{l}0.0105 * * * \\
(0.00289)\end{array}$ & & \\
\hline $\begin{array}{l}\text { Marriage duration when } \\
\text { unilateral divorce introduced } \\
\text { Control for current marital }\end{array}$ & & & $\begin{array}{c}-0.00118 \\
(0.000732)\end{array}$ & $\begin{array}{l}-0.000251 \\
(0.000775)\end{array}$ \\
\hline status & No & Yes & No & Yes \\
\hline Observations & 7,586 & 7,586 & 7,586 & 7,586 \\
\hline$R$-squared & 0.139 & 0.150 & 0.138 & 0.148 \\
\hline
\end{tabular}

Source: Ever-married women ages 50 to 74 at first interview in the SIPP, 1986-2008 Panels.

Notes: Age when unilateral divorce became available is determined based on state of birth. Regressions also control for birth year, state of birth, age fixed effects, race (white, black, Hispanic, other race), education at interview (less than high school, high school, some college, college or more), and urban location at interview. Women born in states where unilateral divorce was never available are omitted from this analysis. Standard errors clustered by state of birth are reported in parentheses.

*/**/*** Significantly different from zero at the 0.10/0.05/0.01 level, two tailed test. 
Table 9: Effect of Age When Unilateral Divorce Became Available on Later-Life Outcomes - Ever-Married Women

\begin{tabular}{|c|c|c|c|}
\hline & $\begin{array}{c}\text { Employed at any point in } \\
\text { panel }\end{array}$ & $\begin{array}{l}\text { Collected social security at } \\
\text { any point in panel }\end{array}$ & Retired at any point in panel \\
\hline \multirow[b]{2}{*}{ Age when unilateral divorce introduced } & \multicolumn{3}{|c|}{ All } \\
\hline & $\begin{array}{c}-0.00877 * * \\
(0.00335)\end{array}$ & $\begin{array}{l}0.00820 * * \\
(0.00350)\end{array}$ & $\begin{array}{l}0.0487 * * * \\
(0.00332)\end{array}$ \\
\hline Marriage duration when unilateral divorce & $-0.000715 * * *$ & $-5.14 e-05$ & $-0.000670 * * *$ \\
\hline introduced & $(0.000205)$ & $(0.000121)$ & $(0.000170)$ \\
\hline Observations & 30,370 & 30,370 & 30,370 \\
\hline \multirow[t]{2}{*}{$R$-squared } & 0.281 & 0.621 & 0.356 \\
\hline & \multicolumn{3}{|c|}{ Low Divorce Risk } \\
\hline Age when unilateral divorce introduced & $\begin{array}{c}0.0617 * * * \\
(0.0156)\end{array}$ & $\begin{array}{c}-0.0159 * * * \\
(0.00514)\end{array}$ & $\begin{array}{l}-0.00851 \\
(0.0162)\end{array}$ \\
\hline Marriage duration when unilateral divorce & $-0.00110 * * *$ & 0.000114 & $-0.00148 * * *$ \\
\hline introduced & $(0.000366)$ & $(0.000156)$ & $(0.000385)$ \\
\hline Observations & 7,582 & 7,582 & 7,582 \\
\hline \multirow[t]{2}{*}{$R$-squared } & 0.255 & 0.641 & 0.303 \\
\hline & \multicolumn{3}{|c|}{ High Divorce Risk } \\
\hline Age when unilateral divorce introduced & $\begin{array}{l}-0.00242 \\
(0.00471)\end{array}$ & $\begin{array}{c}0.00991 * * \\
(0.00464)\end{array}$ & $\begin{array}{l}0.0475 * * * \\
(0.00473)\end{array}$ \\
\hline Marriage duration when unilateral divorce & $-9.11 e-05$ & 0.000216 & $0.00133^{* *}$ \\
\hline introduced & $(0.000846)$ & $(0.000652)$ & $(0.000610)$ \\
\hline Observations & 7,586 & 7,586 & 7,586 \\
\hline$R$-squared & 0.160 & 0.427 & 0.264 \\
\hline
\end{tabular}

Source: Ever-married women ages 60 to 74 at first interview in the SIPP, 1986-2008 Panels.

Notes: Age when unilateral divorce became available is determined based on state of birth. Regressions also control for birth year, state of birth, age fixed effects, race (white, black, Hispanic, other race), education at interview (less than high school, high school, some college and college or more), and urban location at interview. Women born in states where unilateral divorce was never available are omitted from this analysis. Standard errors clustered by state of birth are reported in parentheses.

$* / * * / * * *$ Significantly different from zero at the $0.10 / 0.05 / 0.01$ level, two tailed test. 
Table 10: Effect of Age When Unilateral Divorce Became Available on Later-Life Employment - Subsamples of Ever-Married Women

\begin{tabular}{|c|c|c|c|c|c|}
\hline \multirow{5}{*}{$\begin{array}{l}\text { Age when unilateral divorce } \\
\text { introduced }\end{array}$} & \multicolumn{5}{|c|}{ Employed full time during panel } \\
\hline & White & Non-white & College+ & $\begin{array}{c}\text { Some college or } \\
\text { less }\end{array}$ & $60-69$ \\
\hline & \multicolumn{5}{|c|}{ All } \\
\hline & $-0.0121 * *$ & $0.0329 * * *$ & $0.0577 * * *$ & $-0.0276 * * *$ & $-0.0138 * * *$ \\
\hline & $(0.00509)$ & $(0.0103)$ & $(0.00897)$ & $(0.00598)$ & $(0.000941)$ \\
\hline Marriage duration when & $-0.000812 * * *$ & -0.000439 & $-0.00179 * *$ & $-0.000683^{* * *}$ & $-0.00117 * * *$ \\
\hline unilateral divorce introduced & $(0.000195)$ & $(0.000277)$ & $(0.000749)$ & $(0.000151)$ & $(0.000215)$ \\
\hline Observations & 23,047 & 7,323 & 5,053 & 25,317 & 11,380 \\
\hline \multirow[t]{2}{*}{$R$-squared } & 0.251 & 0.267 & 0.273 & 0.233 & 0.111 \\
\hline & \multicolumn{5}{|c|}{ Low Divorce Risk } \\
\hline Age when unilateral divorce & $\begin{array}{l}0.0688 * * \\
(0.0280)\end{array}$ & $\begin{array}{l}-0.00197 \\
(0.00614)\end{array}$ & $\begin{array}{c}0.0572 * * * \\
(0.0206)\end{array}$ & $\begin{array}{l}0.0778 * * \\
(0.0380)\end{array}$ & $\begin{array}{c}-0.0200 * * * \\
(0.00298)\end{array}$ \\
\hline \multirow[t]{2}{*}{ Marriage duration when } & $-0.000806 * * *$ & $-0.00104 * *$ & -0.00174 & $-0.000654^{* *}$ & $-0.000878 *$ \\
\hline & $(0.000262)$ & $(0.000507)$ & $(0.00164)$ & $(0.000265)$ & $(0.000443)$ \\
\hline Observations & 5,747 & 1,830 & 1,262 & 6,317 & 2,841 \\
\hline \multirow[t]{2}{*}{$R$-squared } & 0.249 & 0.273 & 0.341 & 0.218 & 0.131 \\
\hline & \multicolumn{5}{|c|}{ High Divorce Risk } \\
\hline \multirow[t]{2}{*}{ Age when unilateral divorce } & 0.000621 & $-0.0310 *$ & $0.0489 * *$ & $-0.0128 * *$ & $-0.0295 * * *$ \\
\hline & $(0.00485)$ & $(0.0182)$ & $(0.0186)$ & $(0.00501)$ & $(0.00249)$ \\
\hline \multirow[t]{2}{*}{ Marriage duration when } & -0.00117 & -0.00187 & $-0.00533^{*}$ & -0.00115 & $-0.00185^{* *}$ \\
\hline & $(0.00104)$ & $(0.00164)$ & $(0.00279)$ & $(0.000728)$ & $(0.000725)$ \\
\hline Observations & 5,757 & 1,830 & 1,264 & 6,326 & 2,841 \\
\hline$R$-squared & 0.135 & 0.192 & 0.182 & 0.128 & 0.118 \\
\hline
\end{tabular}

Source: Ever-married women ages 60 to 74 at first interview in the SIPP, 1986-2008 Panels.

Notes: Age when unilateral divorce became available is determined based on state of birth. Regressions also control for birth year, state of birth, age fixed effects, race if applicable (white, black, other race), education at interview if applicable (less than high school, high school, some college), and urban location at interview. Omitted categories: Hispanic, College or more. Women born in states where unilateral divorce was never available are omitted from this analysis. Standard errors clustered by state of birth are reported in parentheses.

$* / * * / * * *$ Significantly different from zero at the $0.10 / 0.05 / 0.01$ level, two tailed test. 
Table 11: Potential Mechanisms - Ever-married Women

\begin{tabular}{|c|c|c|c|}
\hline & $\begin{array}{c}\text { Obtained additional } \\
\text { education after marriage }\end{array}$ & $\begin{array}{l}\text { Have IRA, Keogh, } \\
\text { 401K,403b, or thrift plan }\end{array}$ & $\begin{array}{l}\text { Total market value of all } \\
\text { retirement accounts in own } \\
\text { name }\end{array}$ \\
\hline \multirow[b]{2}{*}{ Age when unilateral divorce introduced } & \multicolumn{3}{|c|}{ All ever-married women } \\
\hline & $\begin{array}{l}0.0284 * * * \\
(0.00175)\end{array}$ & $\begin{array}{l}0.0244^{* * *} \\
(0.00409)\end{array}$ & $\begin{array}{c}-3,125 * * * \\
(459.5)\end{array}$ \\
\hline Observations & 30,275 & 21,830 & 21,837 \\
\hline \multirow[t]{2}{*}{$R$-squared } & 0.608 & 0.230 & 0.063 \\
\hline & \multicolumn{3}{|c|}{ Low Divorce Risk } \\
\hline Age when unilateral divorce introduced & $\begin{array}{c}0.00613 \\
(0.00892)\end{array}$ & $\begin{array}{l}0.103 * * * \\
(0.0179)\end{array}$ & $\begin{array}{c}-6,657 * * \\
(2,774)\end{array}$ \\
\hline Observations & 7,569 & 5,346 & 5,351 \\
\hline \multirow[t]{2}{*}{$R$-squared } & 0.785 & 0.353 & 0.098 \\
\hline & \multicolumn{3}{|c|}{ High Divorce Risk } \\
\hline Age when unilateral divorce introduced & $\begin{array}{l}0.0279 * * * \\
(0.00223)\end{array}$ & $\begin{array}{c}0.0269 * * * \\
(0.00699)\end{array}$ & $\begin{array}{c}-4,354 * * * \\
(662.3)\end{array}$ \\
\hline Observations & 7,553 & 5,347 & 5,347 \\
\hline$R$-squared & 0.454 & 0.128 & 0.048 \\
\hline
\end{tabular}

Source: Ever-married women ages 60 to 74 at first interview in the SIPP, 1986-2008 Panels.

Notes: Age when unilateral divorce became available is determined based on state of birth. Regressions also control for birth year, state of birth, age fixed effects, race (white, black, Hispanic, other race), education at interview (less than high school, high school, some college and college or more), urban location at interview, and age at marriage. Women born in states where unilateral divorce was never available are omitted from this analysis. Standard errors clustered by state of birth are reported in parentheses.

$* / * * / * * *$ Significantly different from zero at the $0.10 / 0.05 / 0.01$ level, two tailed test. 


\begin{tabular}{|c|c|c|c|c|c|c|c|c|}
\hline & \multicolumn{2}{|c|}{ Ever-married women } & \multicolumn{2}{|c|}{ Ever-divorced women } & \multicolumn{2}{|c|}{$\begin{array}{c}\text { Women where } \\
\text { unilateral divorce ever } \\
\text { available }\end{array}$} & \multicolumn{2}{|c|}{$\begin{array}{l}\text { Ever-divorced women } \\
\text { where unilateral } \\
\text { divorce ever available }\end{array}$} \\
\hline & Mean & $\begin{array}{c}\text { Std. } \\
\text { Deviation }\end{array}$ & Mean & $\begin{array}{c}\text { Std. } \\
\text { Deviation }\end{array}$ & Mean & $\begin{array}{c}\text { Std. } \\
\text { Deviation }\end{array}$ & Mean & $\begin{array}{c}\text { Std. } \\
\text { Deviation }\end{array}$ \\
\hline Age & 60.76 & 7.11 & 59.34 & 6.77 & 60.72 & 7.08 & 59.35 & 6.76 \\
\hline \multicolumn{9}{|l|}{ Marital status at first SIPP interview } \\
\hline Currently married & 0.68 & 0.47 & 0.44 & 0.50 & 0.70 & 0.46 & 0.46 & 0.50 \\
\hline Currently divorced & 0.14 & 0.35 & 0.44 & 0.50 & 0.13 & 0.34 & 0.43 & 0.49 \\
\hline Currently separated & 0.01 & 0.12 & 0.02 & 0.13 & 0.01 & 0.11 & 0.02 & 0.12 \\
\hline Currently widowed & 0.17 & 0.37 & 0.10 & 0.30 & 0.15 & 0.36 & 0.10 & 0.30 \\
\hline Ever divorced & 0.32 & 0.47 & 1.00 & 0.00 & 0.31 & 0.46 & 1.00 & 0.00 \\
\hline Age at divorce (conditional on divorce) & 33.61 & 9.97 & 33.61 & 9.97 & 33.41 & 9.93 & 33.41 & 9.93 \\
\hline Divorced by 50 & 0.29 & 0.46 & 0.98 & 0.15 & 0.29 & 0.45 & 0.98 & 0.16 \\
\hline Age at marriage & 22.08 & 5.79 & 20.85 & 4.45 & 21.99 & 5.70 & 20.77 & 4.37 \\
\hline \multicolumn{9}{|l|}{ Education at first SIPP interview } \\
\hline Less than HS & 0.19 & 0.40 & 0.18 & 0.39 & 0.19 & 0.40 & 0.18 & 0.39 \\
\hline High school graduate & 0.37 & 0.48 & 0.32 & 0.47 & 0.37 & 0.48 & 0.32 & 0.47 \\
\hline Some college & 0.26 & 0.44 & 0.32 & 0.47 & 0.27 & 0.44 & 0.33 & 0.47 \\
\hline College or more & 0.17 & 0.37 & 0.17 & 0.38 & 0.17 & 0.37 & 0.16 & 0.37 \\
\hline \multicolumn{9}{|l|}{ Education at marriage } \\
\hline Less than HS & 0.28 & 0.45 & 0.32 & 0.47 & 0.32 & 0.47 & 0.34 & 0.47 \\
\hline High school graduate & 0.40 & 0.49 & 0.38 & 0.49 & 0.38 & 0.48 & 0.37 & 0.48 \\
\hline Some college & 0.24 & 0.43 & 0.25 & 0.43 & 0.23 & 0.42 & 0.24 & 0.43 \\
\hline College or more & 0.08 & 0.26 & 0.05 & 0.22 & 0.07 & 0.25 & 0.05 & 0.21 \\
\hline $\begin{array}{l}\text { Obtained additional education after } \\
\text { marriage }\end{array}$ & 0.80 & 0.40 & 0.85 & 0.36 & 0.80 & 0.40 & 0.85 & 0.36 \\
\hline Obtained additional degree after marriage & 0.28 & 0.45 & 0.39 & 0.49 & 0.28 & 0.45 & 0.39 & 0.49 \\
\hline Worked during $1^{\text {st }}$ marriage & 0.66 & 0.47 & 0.63 & 0.48 & 0.66 & 0.47 & 0.63 & 0.48 \\
\hline Employed full time at any point in panel & 0.33 & 0.47 & 0.43 & 0.50 & 0.33 & 0.47 & 0.43 & 0.50 \\
\hline Employed at any point in panel & 0.49 & 0.50 & 0.58 & 0.49 & 0.49 & 0.50 & 0.58 & 0.49 \\
\hline Employed full time in first panel month & 0.28 & 0.45 & 0.36 & 0.48 & 0.27 & 0.45 & 0.36 & 0.48 \\
\hline Collected social security at any point in panel & 0.53 & 0.50 & 0.48 & 0.50 & 0.52 & 0.50 & 0.48 & 0.50 \\
\hline Retired at any point in panel & 0.46 & 0.50 & 0.44 & 0.50 & 0.45 & 0.50 & 0.43 & 0.50 \\
\hline
\end{tabular}




\begin{tabular}{|c|c|c|c|c|c|c|c|c|}
\hline \multirow{4}{*}{$\begin{array}{l}\text { Have IRA, Keogh, } 401 \mathrm{~K}, 403 \mathrm{~b} \text {, or Thrift } \\
\text { plan } \\
\text { Total market value all retirement accounts } \\
\text { in own name }\end{array}$} & \multicolumn{2}{|c|}{ Ever-married women } & \multicolumn{2}{|c|}{ Ever-divorced women } & \multicolumn{2}{|c|}{$\begin{array}{c}\text { Women where } \\
\text { unilateral divorce ever } \\
\text { available }\end{array}$} & \multicolumn{2}{|c|}{$\begin{array}{c}\text { Ever-divorced women } \\
\text { where unilateral } \\
\text { divorce ever available }\end{array}$} \\
\hline & Mean & $\begin{array}{c}\text { Std. } \\
\text { Deviation } \\
\end{array}$ & Mean & $\begin{array}{c}\text { Std. } \\
\text { Deviation }\end{array}$ & Mean & $\begin{array}{c}\text { Std. } \\
\text { Deviation }\end{array}$ & Mean & $\begin{array}{c}\text { Std. } \\
\text { Deviation } \\
\end{array}$ \\
\hline & 0.48 & 0.50 & 0.44 & 0.50 & 0.49 & 0.50 & 0.45 & 0.50 \\
\hline & 8,461 & 32,251 & 9,739 & 33,833 & 82,967 & 31,737 & 9,630 & 33,536 \\
\hline Observations & 54,964 & & 17,970 & & 49,882 & & 16,174 & \\
\hline
\end{tabular}

Source: Ever-married women age 50-74 in the SIPP 1986-2008 Panels. 
Appendix Table 2A: Trends in Women’s Employment by Age -Women Age 50-59

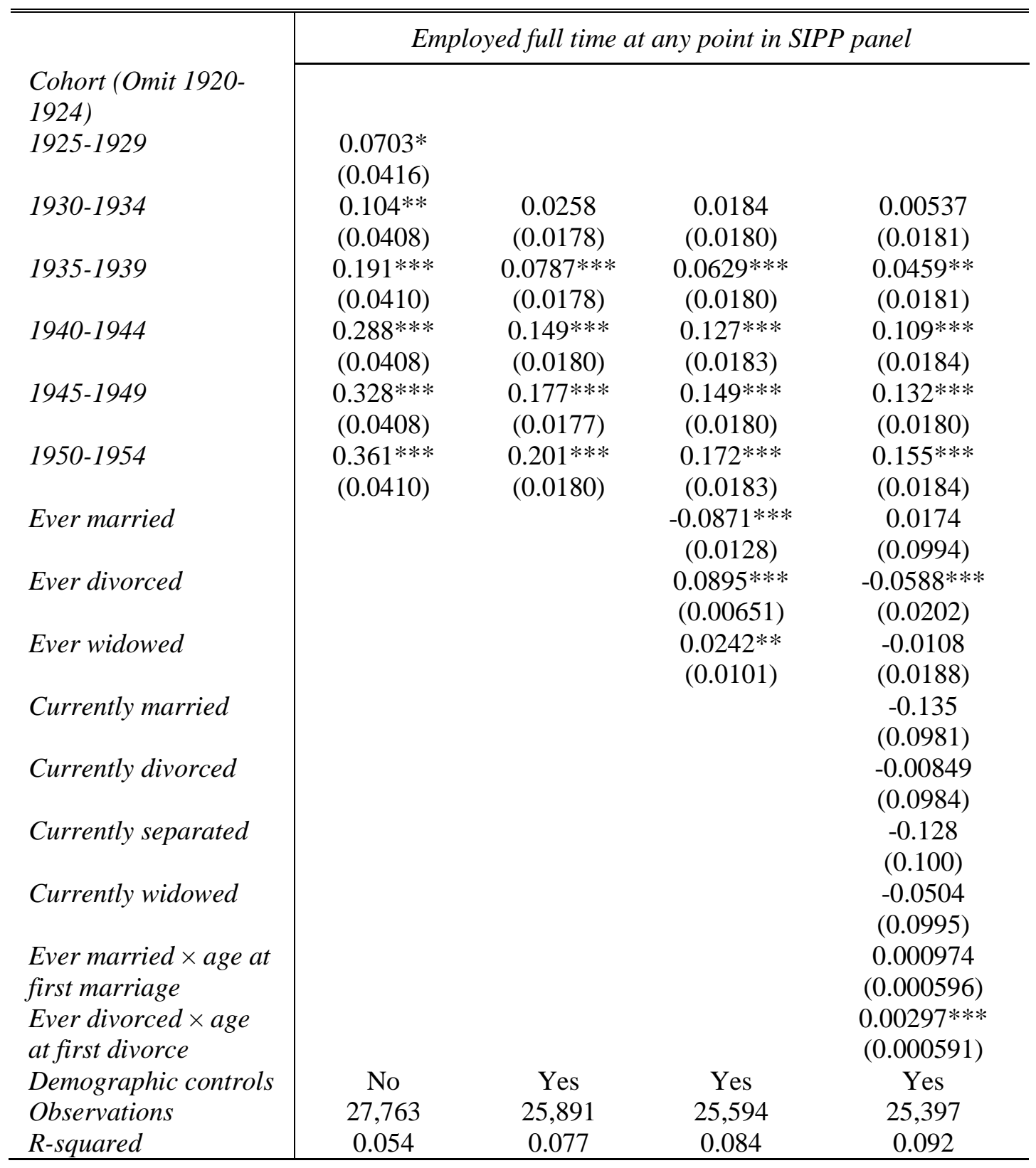

Source: Women ages 50 to 59 at first interview in the SIPP, 1986-2008 Panels.

Notes: All columns control for age fixed effects. Columns two to five additionally control for race (white, black, Hispanic, other race), education at interview (less than high school, high school, some college, college or more), and urban location at interview. Robust standard errors in parentheses.

$* / * * / * * *$ Significantly different from zero at the $0.10 / 0.05 / 0.01$ level, two tailed test. 
Appendix Table 2B: Trends in Women’s Employment by Age -Women Age 60-64

\begin{tabular}{|c|c|c|c|c|}
\hline \multirow{3}{*}{$\begin{array}{l}\text { Cohort (Omit 1920- } \\
\text { 1924) } \\
1925-1929\end{array}$} & \multicolumn{4}{|c|}{ Employed full time at any point in SIPP panel } \\
\hline & & & & \\
\hline & $\begin{array}{c}0.0341^{* * *} \\
(0.0115)\end{array}$ & $\begin{array}{l}0.0274 * \\
(0.0140)\end{array}$ & $\begin{array}{c}0.0164 \\
(0.0143)\end{array}$ & $\begin{array}{l}0.00210 \\
(0.0144)\end{array}$ \\
\hline 1930-1934 & $\begin{array}{c}0.0938 * * * \\
(0.0131)\end{array}$ & $\begin{array}{c}0.0717 * * * \\
(0.0159)\end{array}$ & $\begin{array}{c}0.0605^{* * *} \\
(0.0162)\end{array}$ & $\begin{array}{c}0.0424 * * * \\
(0.0163)\end{array}$ \\
\hline $1935-1939$ & $\begin{array}{c}0.145^{* * *} \\
(0.0142)\end{array}$ & $\begin{array}{c}0.111^{* * *} \\
(0.0170)\end{array}$ & $\begin{array}{c}0.0933 * * * \\
(0.0173)\end{array}$ & $\begin{array}{c}0.0799 * * * \\
(0.0174)\end{array}$ \\
\hline 1940-1944 & $\begin{array}{c}0.167 * * * \\
(0.0128)\end{array}$ & $\begin{array}{c}0.128 * * * \\
(0.0155)\end{array}$ & $\begin{array}{l}0.107^{* * *} \\
(0.0159)\end{array}$ & $\begin{array}{c}0.0912 * * * \\
(0.0160)\end{array}$ \\
\hline $1945-1949$ & $\begin{array}{l}0.216^{* * *} \\
(0.0149)\end{array}$ & $\begin{array}{c}0.166 * * * \\
(0.0177)\end{array}$ & $\begin{array}{c}0.144 * * * \\
(0.0180)\end{array}$ & $\begin{array}{c}0.128 * * * \\
(0.0182)\end{array}$ \\
\hline $1950-1954$ & & & & \\
\hline Ever married & & & $\begin{array}{c}-0.0877 * * * \\
(0.0217)\end{array}$ & $\begin{array}{c}-0.0268 \\
(0.147)\end{array}$ \\
\hline Ever divorced & & & $\begin{array}{l}0.0705 * * * \\
(0.00942)\end{array}$ & $\begin{array}{c}-0.0715^{* *} \\
(0.0283)\end{array}$ \\
\hline Ever widowed & & & $\begin{array}{c}0.0261^{* *} \\
(0.0104)\end{array}$ & $\begin{array}{l}0.00439 \\
(0.0205)\end{array}$ \\
\hline Currently married & & & & $\begin{array}{l}-0.120 \\
(0.145)\end{array}$ \\
\hline Currently divorced & & & & $\begin{array}{l}0.0251 \\
(0.146)\end{array}$ \\
\hline Currently separated & & & & $\begin{array}{c}-0.0784 \\
(0.148)\end{array}$ \\
\hline Currently widowed & & & & $\begin{array}{l}-0.0644 \\
(0.146)\end{array}$ \\
\hline $\begin{array}{l}\text { Ever married } \times \text { age } \\
\text { at first marriage }\end{array}$ & & & & $\begin{array}{c}0.00228 * * * \\
(0.000755)\end{array}$ \\
\hline $\begin{array}{l}\text { Ever divorced } \times \text { age } \\
\text { at first divorce }\end{array}$ & & & & $\begin{array}{l}0.00245^{* * *} \\
(0.000834)\end{array}$ \\
\hline $\begin{array}{l}\text { Demographic } \\
\text { controls }\end{array}$ & No & Yes & Yes & Yes \\
\hline Observations & 12,686 & 11,854 & 11,755 & 11,665 \\
\hline$R$-squared & 0.052 & 0.070 & 0.076 & 0.087 \\
\hline
\end{tabular}

Source: Women ages 60 to 64 at first interview in the SIPP, 1986-2008 Panels.

Notes: All columns control for age fixed effects. Columns two to five additionally control for race (white, black, Hispanic, other race), education at interview (less than high school, high school, some college, college or more), and urban location at interview. Robust standard errors in parentheses.

$* / * * / * * *$ Significantly different from zero at the $0.10 / 0.05 / 0.01$ level, two tailed test. 
Appendix Table 2C: Trends in Women’s Employment by Age -Women Age 65-69

\begin{tabular}{|c|c|c|c|c|}
\hline \multirow{3}{*}{$\begin{array}{l}\text { Cohort (Omit 1920- } \\
\text { 1924) } \\
1925-1929\end{array}$} & \multicolumn{4}{|c|}{ Employed full time at any point in SIPP panel } \\
\hline & & & & \\
\hline & $\begin{array}{l}0.0330 * * * \\
(0.00754)\end{array}$ & $\begin{array}{l}0.0259 * * * \\
(0.00767)\end{array}$ & $\begin{array}{l}0.0232 * * * \\
(0.00768)\end{array}$ & $\begin{array}{c}0.0235^{* * * *} \\
(0.00769)\end{array}$ \\
\hline $1930-1934$ & $\begin{array}{l}0.0620 * * * \\
(0.00905)\end{array}$ & $\begin{array}{l}0.0494 * * * \\
(0.00976)\end{array}$ & $\begin{array}{l}0.0455^{* * *} \\
(0.00974)\end{array}$ & $\begin{array}{l}0.0447 * * * \\
(0.00973)\end{array}$ \\
\hline $1935-1939$ & $\begin{array}{l}0.0897 * * * \\
(0.00881)\end{array}$ & $\begin{array}{l}0.0752 * * * \\
(0.00892)\end{array}$ & $\begin{array}{l}0.0682 * * * \\
(0.00885)\end{array}$ & $\begin{array}{l}0.0662 * * * \\
(0.00889)\end{array}$ \\
\hline $1940-1944$ & $\begin{array}{c}0.106^{* * *} \\
(0.0110)\end{array}$ & $\begin{array}{c}0.0858 * * * \\
(0.0113)\end{array}$ & $\begin{array}{c}0.0766^{* * *} \\
(0.0114)\end{array}$ & $\begin{array}{c}0.0772 * * * \\
(0.0114)\end{array}$ \\
\hline $1945-1949$ & & & & \\
\hline 1950-1954 & & & & \\
\hline Ever married & & & $\begin{array}{c}-0.0676 * * * \\
(0.0183)\end{array}$ & $\begin{array}{l}-0.124 \\
(0.105)\end{array}$ \\
\hline Ever divorced & & & $\begin{array}{c}0.0688 * * * \\
(0.00802)\end{array}$ & $\begin{array}{c}0.0258 \\
(0.0250)\end{array}$ \\
\hline Ever widowed & & & $\begin{array}{l}0.0226 * * * \\
(0.00675)\end{array}$ & $\begin{array}{c}0.0132 \\
(0.0147)\end{array}$ \\
\hline Currently married & & & & $\begin{array}{l}0.0179 \\
(0.104)\end{array}$ \\
\hline Currently divorced & & & & $\begin{array}{c}0.118 \\
(0.105)\end{array}$ \\
\hline Currently separated & & & & $\begin{array}{l}0.0733 \\
(0.111)\end{array}$ \\
\hline Currently widowed & & & & $\begin{array}{l}0.0438 \\
(0.105)\end{array}$ \\
\hline $\begin{array}{l}\text { Ever married } \times \text { age } \\
\text { at first marriage }\end{array}$ & & & & $\begin{array}{l}0.00144 * * \\
(0.000605)\end{array}$ \\
\hline $\begin{array}{l}\text { Ever divorced } \times \text { age } \\
\text { at first divorce }\end{array}$ & & & & $\begin{array}{c}0.000140 \\
(0.000741)\end{array}$ \\
\hline $\begin{array}{l}\text { Demographic } \\
\text { controls }\end{array}$ & No & Yes & Yes & Yes \\
\hline Observations & 10,057 & 10,055 & 9,978 & 9,895 \\
\hline$R$-squared & 0.021 & 0.030 & 0.040 & 0.047 \\
\hline
\end{tabular}

Source: Women ages 65 to 69 at first interview in the SIPP, 1986-2008 Panels.

Notes: All columns control for age fixed effects. Columns two to five additionally control for race (white, black, Hispanic, other race), education at interview (less than high school, high school, some college, college or more), and urban location at interview. Robust standard errors in parentheses.

$* / * * / * * *$ Significantly different from zero at the $0.10 / 0.05 / 0.01$ level, two tailed test. 
Appendix Table 3: Unilateral Divorce Laws

\begin{tabular}{|c|c|c|c|c|c|c|c|}
\hline & $\begin{array}{l}\text { Definition 1: No-fault } \\
\text { dissolution, no } \\
\text { separation requirement } \\
\end{array}$ & $\begin{array}{l}\text { Definition 2: No-fault } \\
\text { dissolution, allows for } \\
\text { separation requirement } \\
\end{array}$ & $\begin{array}{c}\text { Definition 3: No-fault } \\
\text { dissolution, no separation, } \\
\text { no-fault property/alimony }\end{array}$ & $\begin{array}{c}\text { Wolfers } \\
\text { (2006) }\end{array}$ & $\begin{array}{l}\text { Gruber } \\
\text { (2004) }\end{array}$ & $\begin{array}{l}\text { Friedberg } \\
\text { (1998) }\end{array}$ & $\begin{array}{l}\text { Voena } \\
\text { (2015) }\end{array}$ \\
\hline$A K$ & 1963 & 1963 & 1974 & 1935 & 1935 & no & pre-1967 \\
\hline$A L$ & 1971 & 1971 & 1971 & 1971 & 1971 & 1971 & 1971 \\
\hline$A R$ & no & 1979 & no & no & no & no & no \\
\hline$A Z$ & 1974 & 1974 & 1974 & 1973 & 1973 & 1973 & 1973 \\
\hline$C A$ & 1970 & 1970 & 1970 & 1970 & 1970 & 1970 & 1970 \\
\hline $\mathrm{CO}$ & 1972 & 1972 & 1972 & 1971 & 1972 & 1971 & 1972 \\
\hline$C T$ & 1973 & 1973 & no & 1973 & 1973 & 1973 & 1973 \\
\hline$D C$ & no & 1977 & no & no & no & no & no \\
\hline$D E$ & 1974 & 1968 & no & no & 1968 & no & 1968 \\
\hline$F L$ & 1971 & 1971 & 1978 & 1971 & 1971 & 1971 & 1971 \\
\hline$G A$ & 1973 & 1973 & no & 1973 & 1973 & 1973 & 1973 \\
\hline$H I$ & 1972 & 1972 & 1972 & 1973 & 1972 & 1973 & 1972 \\
\hline$I A$ & 1970 & 1970 & 1972 & 1970 & 1970 & 1970 & 1970 \\
\hline ID & 1971 & 1971 & 1990 & 1971 & 1971 & 1971 & 1971 \\
\hline$I L$ & no & 1984 & no & no & no & no & no \\
\hline IN & 1973 & 1973 & 1973 & 1973 & 1973 & 1973 & 1973 \\
\hline KS & 1969 & 1969 & 1990 & 1969 & 1969 & 1969 & 1969 \\
\hline$K Y$ & 1972 & 1972 & 1987 & 1972 & 1972 & 1972 & 1972 \\
\hline$L A$ & no & no & no & no & no & no & no \\
\hline$M A$ & 1975 & 1975 & no & 1975 & 1975 & 1975 & 1975 \\
\hline$M D$ & no & 1983 & no & no & no & no & no \\
\hline$M E$ & 1973 & 1973 & 1985 & 1973 & 1973 & 1973 & 1973 \\
\hline$M I$ & 1972 & 1972 & no & 1972 & 1972 & 1972 & 1972 \\
\hline$M N$ & 1974 & 1974 & 1974 & 1974 & 1974 & 1974 & 1974 \\
\hline$M O$ & no & 1973 & no & no & no & no & no \\
\hline
\end{tabular}


Appendix Table 3, continued

\begin{tabular}{|c|c|c|c|c|c|c|c|}
\hline & $\begin{array}{l}\text { Definition 1: No-fault } \\
\text { dissolution, no } \\
\text { separation requirement } \\
\end{array}$ & $\begin{array}{c}\text { Definition 2: No-fault } \\
\text { dissolution, allows for } \\
\text { separation requirement }\end{array}$ & $\begin{array}{c}\text { Definition 3: No-fault } \\
\text { dissolution, no separation, } \\
\text { no-fault property/alimony }\end{array}$ & $\begin{array}{c}\text { Wolfers } \\
\text { (2006) }\end{array}$ & $\begin{array}{l}\text { Gruber } \\
\text { (2004) }\end{array}$ & $\begin{array}{c}\text { Friedberg } \\
\text { (1998) }\end{array}$ & $\begin{array}{l}\text { Voena } \\
\text { (2015) }\end{array}$ \\
\hline$M S$ & no & no & no & no & no & no & no \\
\hline$M T$ & 1975 & 1975 & 1975 & 1975 & 1973 & 1975 & 1973 \\
\hline$N C$ & no & no & no & no & no & no & no \\
\hline$N D$ & 1971 & 1971 & 1971 & 1971 & 1971 & 1971 & 1971 \\
\hline$N E$ & 1972 & 1972 & 1972 & 1972 & 1972 & 1972 & 1972 \\
\hline$N H$ & 1971 & 1971 & 1971 & 1971 & 1971 & 1971 & 1971 \\
\hline$N J$ & no & 1971 & no & no & no & no & no \\
\hline$N M$ & 1973 & 1973 & 1976 & 1973 & 1933 & 1973 & 1973 \\
\hline$N V$ & 1973 & 1973 & 1973 & 1973 & 1967 & 1973 & 1967 \\
\hline$N Y$ & no & no & no & no & no & no & no \\
\hline $\mathrm{OH}$ & no & 1974 & no & no & no & no & 1992 \\
\hline OK & 1953 & 1953 & 1975 & 1953 & 1953 & no & pre-1967 \\
\hline$O R$ & 1971 & 1971 & 1971 & 1973 & 1971 & 1973 & 1971 \\
\hline$P A$ & no & 1980 & no & no & no & no & no \\
\hline$R I$ & 1976 & 1976 & no & 1976 & 1975 & 1976 & 1975 \\
\hline$S C$ & no & 1969 & no & no & no & no & no \\
\hline$S D$ & 1985 & 1985 & no & 1985 & 1985 & 1985 & 1985 \\
\hline$T N$ & no & 1977 & no & no & no & no & no \\
\hline$T X$ & 1970 & 1970 & no & 1974 & 1970 & 1974 & 1970 \\
\hline$U T$ & 1987 & 1987 & no & no & 1987 & & 1987 \\
\hline$V A$ & no & 1960 & no & no & no & no & no \\
\hline$V T$ & no & 1969 & no & no & no & no & no \\
\hline WA & 1973 & 1973 & 1973 & 1973 & 1973 & 1973 & 1973 \\
\hline WI & no & 1978 & no & no & 1978 & no & 1978 \\
\hline$W V$ & no & 1977 & no & no & no & no & 1984 \\
\hline$W Y$ & 1977 & 1977 & no & 1977 & 1977 & 1977 & 1977 \\
\hline
\end{tabular}


Appendix Table 4: Effect of Age When Unilateral Divorce Became Available on Indicator for Divorce by Age 50 - Ever-Married Women

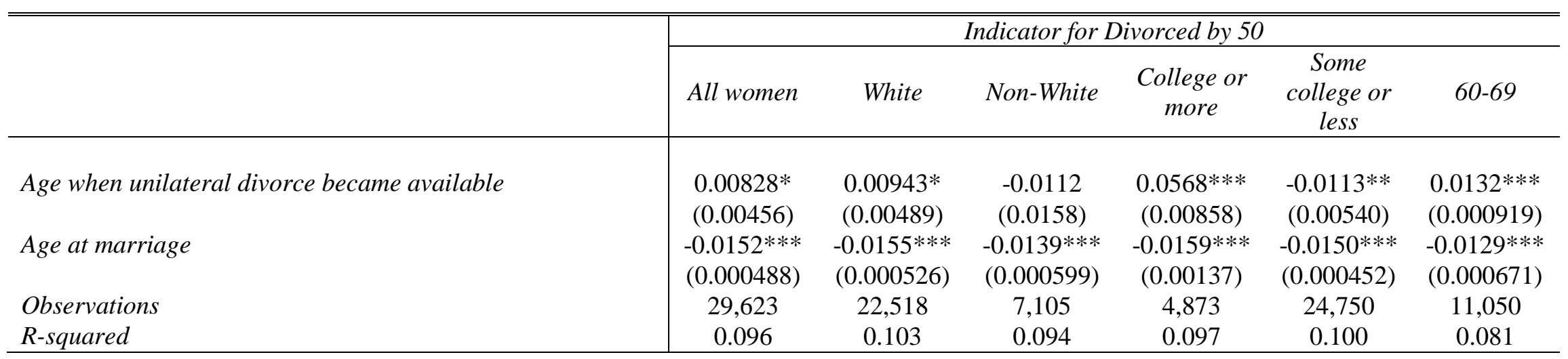

Source: Ever-married women ages 50 to 74 at first interview in the SIPP, 1986-2008 Panels.

Notes: Age when unilateral divorce became available is determined based on state of birth. Regressions also control for birth year, state of birth, age fixed effects, race (if applicable; white, black, Hispanic, other race), education at interview (if applicable; less than high school, high school, some college and college or more) and urban location at interview. Women born in states where unilateral divorce was never available are omitted from this analysis. Standard errors clustered by state of birth are reported in parentheses.

$* / * * / * * *$ Significantly different from zero at the $0.10 / 0.05 / 0.01$ level, two tailed test. 